\title{
УДК 902
}

\section{СТОЯНКА ОРЕХОВО-ДОНЕЦКОЕ 3 В СРЕДНЕМ ПОДОНЦОВЬЕ. К ХАРАКТЕРИСТИКЕ ОДНОЙ ИЗ ПОВОРОТНЫХ ВЕХ В ИСТОРИИ ДНЕПРО-ДОНЕЦКОГО НЕОЛИТА} (C) 2014

\author{
A.Ф. Горелик, кандидат исторических наук, доцент, независимый исследователь \\ Бохум $(Ф Р Г)$ \\ A.B. Цыбрий, кандидат исторических наук, старший научный сотрудник \\ Донское археологическое общество, Ростов-на-Дону (Россия)
}

Аннотация. В статье впервые публикуются материалы исследований стоянки раннего неолита ОреховоДонецкое 3 в Среднем Подонцовье. Обоснована принадлежность данного памятника к ряду многочисленных стоянок охотников-собирателей-рыболовов так называемого Бондарихинского этапа, распространившихся в 6 тыс. calBC на территории левобережья Северского Донца и, отчасти, в Нижнем Поднепровье. Авторы анализируют причины значительных демографических трансформаций на рубеже мезолита-неолита в этом регионе, характеризуют связи и контакты населения Донецкой культуры, показывают значимость социальных изменений как предпосылки процесса «неолитизации».

Ключевые слова: мезолит; неолит; «неолитизация»; осевой момент; Донецкая культура.

Стоянка расположена в 1 км к западу от села ОреховоДонецкое Славяносербского района Луганской области с координатами $48^{\circ} 46^{\prime} 15^{\prime \prime}$ северной широты и $38^{\circ} 48^{\prime} 07^{\prime \prime}$ восточной долготы (рис. 1). Она приурочена к мысу отчетливо выраженной в рельефе 1-й надпойменной песчаной террасы левого берега р. Северский Донец (рис. 2). Мыс с дюновидным всхолмлением на поверхности, высотой 13-15 м над поймой образовался, возможно, в силу поворота или периодических разливов реки в северном направлении, в сторону тыльного шва надпойменной террасы.

Стоянка занимает среднюю часть поверхности дюны. В 1982 и 1984 годах здесь экспедицией Луганского краеведческого музея под руководством А.Ф. Горелика была вскрыта площадь 116 кв.м. Раскопки тогда велись по традиционной в советской археологии методике: условные горизонты песка мощностью до 15 см косо срезались лопатой до появления концентрации находок, которая затем расчищалась с помощью ножа. Все находки фиксировались по слоям на плане. Наиболее полная стратиграфия памятника была прослежена в южной части раскопа по линии квадратов Д (рис. 3). Сверху вниз здесь установлены следующие почвенные слои: 1. супесь гумусированная элювиированная - темно-серая, пахотная, рыхлая, бесструктурная, мощностью 0,2-0,4 м; 2. песок желтый элювиированный, бесструктурный с редкими псевдофибрами, нижняя граница - нечеткая, мощностью 0,4 м; 3. песок светло-желтый-белый иллювиированный с красно-бурыми разорванными псевдофибрами, толщиной 0,5-10 см, прослежен слой до 0,9 м В северной части раскопа гумусированная супесь перекрывалась тонким дерновым слоем (рис. 4).

Раскопки показали, что данный участок поверхности берега Северского Донца активно использовался в различные периоды времени. Были расчищены несколько культурных горизонтов. В гумусированной супеси встречены фрагменты казачьей посуды, керамика эпохи поздней бронзы, а на границе с нижележащим слоем песка развал крупной части горшка эпохи ранней бронзы (рис. $5,7,11$ ) и крупный фрагмент стенки сосуда энеолитического времени (рис. 5, 9,10). Керамика ранней бронзы была найдена и на поверхности - в котловине выдувания, а также в противопожарной распашке. В желтом элювиированном песке, главным образом, в его средней и нижней части, располагались артефакты начала неолита. Здесь же были встречены единичные фрагменты керамики позднего неолита-энеолита. На площади раскопа были обнаружены два захоронения - одно салтово-маяцкой культуры, второе - эпохи ранней бронзы (?) (рис. $3 ; 4)$, а также многочисленные захоронения животных исторического времени.

Наиболее сложной проблемой источниковедческой критики нео-энеолитических материалов стоянки является ответ на вопрос об их культурно-хронологической гомогенности. В частности, как соотносятся находки керамики и каменный инвентарь? Стратиграфия памятника дает основание утверждать, что два фрагмента крупной стенки энеолитического сосуда были отложены после формирования слоя с кремневой индустрией. Черепки принадлежат толстостенному сосуду с внешней поверхностью желтого-охристого цвета, с плотным по консистенции тестом черного цвета с примесью песка и, возможно, органики в переработанном виде (рис. 5, 9-10). Со стороны внешней поверхности они покрыты сплошным орнаментом, а по внутренней поверхности нанесены расчесы. Орнаментальная композиция состоит из параллельных полос сдвоенного зигзага, разделенных лентами из коротких поперечных штрихов. По мнению В.Я. Кияшко, зигзаг, широко распространенный в раннем энеолите, в данном случае выполнен в сравнительно более поздней манере «резным штампом на конце палочки или, скорее, на конце мелкого ребра, судя по неравно изогнутым сторонам на отпечатке». Штрихи, по всей видимости, выполнены сдвоенными оттисками мелкозубчатого, наклонно поставленного штампа, «замыленными» со временем. На одном фрагменте от части сосуда, переходящей ко дну, видно, что к расположенному с края зигзагу, примыкает полоса заштрихованных треугольников, выполненных прочерченными линиями. В.Я. Кияшко считает данный тип керамики очень своеобразным, не имеющим прямых аналогий. Лишь такие элементы орнамента, как ленты из оттисков зубчатого штампа, имеют аналогии в позднем Среднем Стоге (Балка Квитяна, или Цегельня), сплошное покрытие орнаментом встречено на востоке степной зоны, например, в Хвалынском могильнике. Подобная керамика попадается, по его мнению, и в репинское время и несколько позже в лесостепной зоне, где она датируется рубежом IV-III тыс. до н.э. (по некалиброванной шкале). Также энеолитическим временем датируются два фрагмента толстостенных сосудов светло-желтого цвета обжига, с примесью в тесте песка и расчесами по внутренней поверхности (рис. 5, 5,8). Они украшены оттисками «шагающей гребенки», образующей елочный узор, и, судя по одному негативно-ямочному вдавлению на одном из черепков (рис. 5,8$)$, рядами ямок. Гребенка - тонкая, мелкая, ее оттиски состоят из большого числа зубчиков. Этот вид керамики имеет аналогии в материалах III-го этапа поселения Самсоновское на Нижнем Дону [1, рис. 8:6], а также Веревкинских хуторов 14 [2, рис. 51: 3]. По мнению А.Н. Гея, автора раскопок Самсоновского поселения, такая керамика относится уже бесспорно к энеолитическому времени, возможно, к раннерепинскому времени или к этапу, который ему предшествует [1, с. 128]. По-видимому, к этому же культурно-хронологическому комплексу относятся фрагменты керамики серого цвета обжига, орнаментированные длинными косо поставленными оттисками крупнозубчатой гребенки, иногда образующими зигзаг (рис. $5,1,2,4)$. Один из этих черепков 
- фрагмент короткой шейки сосуда, орнаментированной крупной грубой гребенкой ниже горизонтальной полосы вдавлений, а при переходе к плечикам сосуда - многорядными горизонтальными прочерченными линиями. Два других - вертикальных венчика с уплощенным срезом, в одном случае утолщенным в обе стороны, в другом - только на внутренней стороне. Значительно более архаично выглядит неорнаментированный фрагмент тонкостенного сосуда с примесью в тесте травы и кровавика (рис. 5, 3), который был найден в одном слое с кремневыми изделиями, что, возможно, указывает на их взаимосвязь.

Как было отмечено выше, фрагменты горшка ранней бронзы занимали примерно такую же стратиграфическую позицию, что и энеолитические черепки. Они имели поверхность охристых оттенков с включениями мелкотолченой ракушки, «кровавика», «вымокающих» зерен, отчего на поверхности образовались редкие оспинки. Орнаментальная композиция состоит из горизонтальных рядов протащенных двузубых небрежных наколов, нанесенных на переходе к тулову, вниз спускается сплошная, либо с разрывами, косолинейная штриховка в стиле „отступающей лопаточки“ (рис. 5,7,11). В.Я. Кияшко считает, что орнамент нанесен гладким стерженьком, округлого сечения с поперечным несколько рваным изломом. Один фрагмент украшен двойным оттиском грубого шнура (рис. 5, 6). По мнению В.Я. Кияшко, такая керамика появляется в ранней бронзе, например, в Константиновке, и исчезает к началу катакомбного времени. С учетом фрагмента с оттисками шнура такая керамика может датироваться первой половиной III тыс. до н.э.

Горизонт начала неолита, наиболее репрезентативный для данного памятника, судя по нивелировочным отметкам находок, залегал с наклоном в соответствии с современным рельефом поверхности дюны (рис. 3 ; 4). Падение наблюдалось в сторону старицы Донца, а также в западном направлении. Сохранность культурного слоя сравнительно неплохая, о чем говорит отсутствие следов сортировки материала, наличие локализованных скоплений, «связи» отдельных артефактов. Примером «связей» может служить находка двух фрагментов кремневого артефакта, на расстоянии 0,4 м на одной и той же глубине от поверхности. Вместе с тем, очевидно, что многократное заселение поверхности дюны вело к нарушению целостности ранненеолитического слоя, смешиванию разновременных находок. Критическим недостатком сохранности культурного слоя, как впрочем и почти всех памятников мезолита-неолита Подонцовья на песках, является отсутствие органики.

В восточной части раскопа, на глубине $0,5-0,7$ м от репера, выявлено скопление кремней с слабо выраженными границами N 00001, ориентированное по оси С3-ЮВ, размерами 6,6x4,8 м (рис. 3). На меньшей площади это же скопление было прослежено на глубине 0,7-1 м (рис. 4). Небольшие скопления, подокруглые в плане, были прослежены в центральной части раскопа и его юго-западном углу (рис. 4).

Находки представлены, главным образом, изделиями из кремня, а также обломками глинистого ожелезненного сланца и несколькими изделиями из песчаника. В нескольких случаях был прослежен регулярный, закономерный характер распределения артефактов определенного вида. Так, в составе скопления N 00001 были сосредоточены $90 \%$ нуклеусов на отщепах с боковыми поверхностями скалывания (нуклеусы донецкого типа) и формирующих их сколов. Здесь же были найдены многочисленные обломки глинистого сланца. Обращают внимание места оббивки кремневого сырья и получения заготовок. Так, в квадратах 11-12Б была отмечена повышенная (до 65 единиц на 1 кв. м) концентрация сколов, прежде всего первичных, осколков и чешуек, которая сопровождалась находкой отбойника. В квадратах 12Д-12Г-13Г найдены четыре нуклеуса, крупные гальки и первичные отщепы. В микроскоСамарский научный вестник. 2014. № 3(8) плении в квадратах 13А-13Б, 12А встречены три скола подправки площадок нуклеусов, отмечено повышенное содержание сколов-пластин, что может указывать на расщепление на этом месте нуклеусов. В квадрате 10Б были выявлены остатки кострища в виде маломощного скопления древесных угольков, размерами 0,46х0,16 м. Меньшие по площади скопления угольков обнаружены на других участках раскопа.

При всей ущербности культурного слоя начала неолита можно высказать предположение, что мы имеем дело с остатками относительно кратковременной стоянки, возможно, охотничьего лагеря, в котором среди прочих форм деятельности наибольшее воздействие на формирование слоя оказало ситуативное расщепление кремня и кварцита.

Анализ коллекции изделий из кремня и кварцита, насчитывающей 2570 единиц (таблица 1), представляет большой интерес. Главным образом использовался местный галечный кремень желтого воскового и темносерого цвета, по всей видимости, добываемый в аллювии на Правобережье Донца. Кремень покрыт легкой патиной, отдельные изделия обожжены в огне. Кварцит (менее 1\% всей коллекции), имеющий светло-серый и красноватый цвет, находил ограниченное применение.

Представление об исходном сырье каменной индустрии можно составить по целым и частично расколотым галькам из кремня, доля которых в коллекции стоянки составляет $0,82 \%$. Они имеют вытянутые пропорции, уплощенно-овальную форму, размеры в граничных пределах $8,5 \times 6,5 \times 2-4,5 \times 2 \times 2$ см.

Нуклеусы стоянки $(1,48 \%)$ находятся в различной стадии сработанности и отражают, по всей видимости, разные, но часто стадиально взаимосвязанные, варианты редукции кремневого сырья. Наиболее многочисленны и морфологически выразительны так называемые резцы-струги (нуклеусы донецкого типа) (29 экз.) (Рис. 6). Они изготовлены из массивных отщепов и обломков, были рассчитаны на утилизацию боковых (торцевых) поверхностей скалывания с использованием одной (23 экз.) или двух (шесть экземпляров) поперечно ретушированных площадок-перемычек [3]. Соотношение толщины заготовки к ее ширине как минимум 1:2 является граничным значением, определяющим возможность нуклеусной редукции (там же, 270). Абсолютно аналогичные изделия с меньшими значениями толщины следует рассматривать как сработанные, выбракованные или использованные по иному назначению формы (там же, 271). В ходе ремонтажа в нескольких случаях удалось подобрать пластинчатые сколы, отделенные от этих пренуклеусов (рис. $6,5,8)$. В одном случае был подобран треугольный в поперечном сечении ребристый скол, искривленный в профиле (рис. 6,5$)$. Его удалением была подготовлена боковая грань поверхности расщепления. В другом случае-неправильная пластина (рис. 6, 8). На обоих образцах мы наблюдаем намеренное смещение поверхности скалывания на уплощенную вентральную поверхность заготовки. Это создавало предпосылки для создания боковой поверхности скалывания, состоящей из граней двух-трех пластинчатых снятий. На последующем этапе расщепления с использованием уже отжима процесс редукции приобретал высоко контролируемый характер (там же, 271). Показательна морфология подправочных снятий на отбивной площадке, которые ориентированы с вентральной на дорсальную поверхность (рис. 6,8$)$ ) 17 сколов с такой морфологией были выделены среди пластин стоянки.

Другой вариант подготовки нуклеуса отмечен на пренуклеусе из овально-вытянутой, уплощенной гальки. Здесь одним поперечным сколом была подготовлена площадка, с которой, в области боковых, более узких поверхностей, были сделаны сколы формирования поверхности скалывания. Прочие нуклеусы находятся в более зрелой стадии редукции. Часть из них производна от нуклеусов (пренуклеусов) на отщепах с боковыми поверхностями скалывания. Показательно, что все они одноплощадочны и предназначены для получения 
пластин. Исходя из формы могут быть выделены три пирамидальных нуклеуса, два карандашевидных и два клиновидных. Пирамидальные нуклеусы несут следы расщепления в основном по окружности (рис. 7, 3, 6). У двух из них тыльная поверхность уплощена широкими продольными или поперечными снятиями, которые, повидимому, выравнивали плоскость от неровностей первичной галечной поверхности, готовя ее к регулярному раскалыванию. На одном из нуклеусов этого типа корка сохранялась. Угол отбивной площадки менялся в зависимости от размещения поверхности скалывания, по отношению к которой предпочтение отдавалось скошенной площадке. На карандашевидных нуклеусах площадка находилась под прямым углом к поверхности скалывания, расположенной по окружности (рис. 7, 1, 2). Нуклеусы клиновидной формы имели скошенные площадки. Один из них раскалывался по всему периметру (рис. 7, 4), второй - с одной стороны (рис. 7,5$)$. Подправка площадки велась как мелкими, локальными, так и более крупными, размашистыми снятиями.

Таблица 1 - Технико-типологический состав каменного инвентаря стоянки Орехово-Донецкое 3

\begin{tabular}{|c|c|c|c|c|c|}
\hline КатегоріII & Кол-во & $\%$ & Категориі & Кол-во & \\
\hline Bcero: & 2570 & 100 & $\begin{array}{l}\text { Изделия со вторпчной } \\
\text { обработкой }\end{array}$ & 178 & $6,93 / 100$ \\
\hline $\begin{array}{l}\text { Неиспользованное } \\
\text { сырье }\end{array}$ & 21 & 0,82 & Скребки & 21 & 11,80 \\
\hline Нуклеусы & 38 & 1,48 & Резцы & 37 & 20,79 \\
\hline $\begin{array}{l}\text { Нуклевидные } \\
\text { обломки }\end{array}$ & 11 & 0,43 & $\begin{array}{l}\text { Пластинки и микропластинки с } \\
\text { краевой ретушью }\end{array}$ & 50 & 28,09 \\
\hline $\begin{array}{l}\text { Поперечные сколы } \\
\text { подправок } \\
\text { площадок } \\
\text { нуклеусов }\end{array}$ & 9 & 0,35 & Проколкн, сверла, развертки & 7 & 3,93 \\
\hline $\begin{array}{l}\text { «Продольные» } \\
\text { сколы с нуклеусов }\end{array}$ & 7 & 0,27 & Острня & 7 & 3,93 \\
\hline Ребристые сколы & 43 & 1,67 & Трапецин & 10 & 5,62 \\
\hline Отщепы & 1562 & 60,78 & Скобели & 29 & 16,29 \\
\hline $\begin{array}{l}\text { Пластинчатые } \\
\text { заготовки }\end{array}$ & 486 & 18,91 & Рубящие орудия & 4 & 2,25 \\
\hline ОсколКН, об̆ЛОМКн & 204 & 7,94 & $\begin{array}{l}\text { Обломки рубящих орудий, } \\
\text { сколы подправкн }\end{array}$ & 2 & 1,12 \\
\hline Резцовые отщепки & 8 & 0,31 & Отщепы с ретушью & 6 & 3,37 \\
\hline Отбойники & & 0,12 & Индивидуальные формы & 5 & 2,81 \\
\hline
\end{tabular}

В коллекции отмечены остаточные ядрища, нуклевидные обломки $(0,43 \%)$, а также технические сколы, с помощью которых производилось управление процессом раскалывания: ребристые сколы $(1,67 \%)$, поперечные снятия подправки площадок $(0,35 \%)$.

Отщепы стоянки $(60,78 \%)$ в зависимости от их размеров могут быть дифференцированы на крупные $(\geq 3 \mathrm{~cm})$ $-9 \%$, средние $(>1<3$ см) - 69\% и мелкие $\leq 1$ см $-22 \%$. Довольно высокий (19\%) удельный вес отщепов с коркой подтверждает значимость процессов первичной утилизации кремневого сырья при формировании культурного слоя стоянки.

Пластинчатые заготовки $(18,91 \%)$ в зависимости от ширины распределяются следующим образом: пластины $(\geq 1,5$ см) - 10\%, пластинки $(>0,7<1,5$ см $)-64 \%$, микропластинки $(\leq 0,7$ см) - 26\%. Целые пластинчатые заготовки $(21 \%)$ отличаются правильным огранением относительно прямым профилем. $37 \%$ из них составляют пластинки длиной между 4 и 6 см, единичные образцы имеют длину 7 см, длина 62\% лежит между 3-4 см. Количественно доминируют проксимальные концы пластинчатых заготовок (33\%), значительно меньше медиальных сечений $(25 \%)$ и дистальных концов $(21 \%)$. Около половины проксимальных и дистальных концов имеют длину от 2 до $5 \mathrm{~cm}$, некоторые достигают длины 6-7 см, прочие (50\%) имеют длину менее 2 см.

Среди медиальных сечений наиболее многочисленны изделия с соотношением ширины к длине 1:2, 1:3, 1:4$45 \%$, значительно меньше сечений квадратной $(27 \%)$ и подквадратной $(1: 1,5)$ формы - 20\%.

В коллекции присутствуют три отбойника, два из которых из кремня, а один из кварцита. Один из кремневых отбойников, сравнительно небольшой, размерами $3 \times 2,5 \times 2$ cм, с несколькими участками забитости, мог использоваться в качестве ретушера.

Изделия со вторичной обработкой (6,93\%) (таблиша 1) изготовлены главным образом из пластинок - 70,79\% и в меньшей степени из отщепов - 29,21\%. В группе скребков $(11,8 \%)$ преобладают концевые скребки (10 экз. - 48\%). Они изготовлены на отщепах (семь экз.) и на пластинках (три экз.). Скребковое лезвие арочной формы сформировано симметрично по отношению к центральной оси заготовки (рис. 8, 10,12,14-18). В семи случаях для этого была использована крутая-полукрутая ретушь, в трех - пологая. На рабочем лезвии одного из скребков присутствует выступ так называемая «мордочка» (рис. 8, 15). Морфологически близки скребки на отщепах, обработанные ретушью по части их периметра. Среди них могут быть выделены подокруглые скребки (пять - 24\%) и боковые (три - 14\%). Они обработаны полукрутой и пологой ретушью (рис. 8, 13). Отмечены два скребка на отщепах с ретушью, нанесенной по всему периметру. Один из них - стрельчатый, другой овальной формы с высоким рабочим лезвием (рис. 8, 11).

В группе пластинок и микропластинок с краевой ретушью $(28,09 \%)$ обращает на себя внимание чрезвычайно показательная группа микропластинок с притупленным ретушью краем (16 экз. - 32\%). Они обработаны вертикальной ретушью, «съедающей» край заготовки (рис. 9, 10-20; 30-31). Среди них два изделия с косо усеченным ретушью концом заготовки (рис. 9,15,17), которые, по-видимому, являются фрагментами асимметричных вытянутых треугольников.

Прочие изделия этой группы морфологически менее определенны, в ряде случаев здесь ретушь образовалась в силу срабатывания. Можно выделить пластинки, обработанные регулярной краевой крутой-полукрутой ретушью (14 экз. - 28\%) (рис. 9, 32, 33), пластинки с фрагментарной ретушью (девять экз. - 18\%) (рис. 9, 38, 39), пластинки с регулярной пологой ретушью (семь экз. 14\%) (рис. 9, 40). Единичными образцами представлены пластинки с краевой полукрутой ретушью на спинке и плоской ретушью на брюшке (два экз. - 4\%). Вероятно, что они могли быть использованы в качестве скобелей по кости и рогу. Эти последние могут быть атрибутированы как вкладыши кукрекского типа.

Геометрические микролиты представлены исключительно трапециями/прямоугольниками $(5,62 \%)$. Четыре из них относятся к типу «со струганой спинкой» (рис. 9, 6-9), шесть обработаны крутой ретушью по боковым сторонам (рис. 9, 1-5). Две трапеции/прямоугольники со струганой спинкой - средневысокие (рис. 9, 6,7), две другие - высокие, изготовленные из одной пластины (рис.9, 8,9). Трапеции с крутой ретушью по боковым сторонам симметричны, представлены высокими (два экз.) (рис. 9, 4,5) и средневысокими (четыре экз.) (рис. 9, 1-3) образцами. Особо следует выделить одну трапецию с фасетками плоской вентральной ретуши по боковым сторонам и верхнему основанию (рис. 9,4) и одну трапецию с суженным верхним основанием и слегка выемчатыми боковыми сторонами, намечающими «талию» (рис. 9, 3).

В группе острий $(3,93 \%)$ выделены два острия яниславицкого (донецкого) типа со сломанным основанием (рис. 9, 24, 25), а также острия со скошенным ретушью концом. Последние представлены тремя остро скошенными (рис.9, 21-23) и двумя с усеченными ретушированием концами. Одно из них - ромбовидное (рис. 9,28), второе - асимметричное (рис.9,29).

В группе резцов $(18,97 \%)$ наиболее многочисленны резцы на углу слома заготовки (23 экз. - 34,8\%). В 19 случаях они изготовлены на пластинках, в четырех на отщепах. Резцы этого типа оформлены коротким торцевым снятием, занимающим не более половины длины заготовки. В двух случаях резцовый скол уплощен в направлении вентральной поверхности. 16 резцов имеют одну резцовую кромку (рис. $8,1,2$ ), пять снабжены двумя резцовыми кромками, расположенными на одном конце заготовки (рис. 8, 6), на двух резцах резцовые кромки были расположены диагонально по отношению друг к другу (рис. 8,4). Резцы боковые выемчаторетушные на отщепах представлены восемью образцами 
(12\%). Четыре из них одинарные, оформленные резцовым снятием, уплощенным на вентральную поверхность (рис. 8, 3,7). Морфологически подобны нуклеусам донецкого типа (но с иным соотношением толщины и ширины) четыре билатеральных резца, изготовленные на пластинках (рис. 8, 5). Уплощенные на брюшко резцовые снятия здесь спроецированны с ретушированной выемчатой площадки.

Среди двухгранных резцов один клювовидный $($ рис. 8,9$)$ и три срединных (рис. 8, 8). Следует отметить два срединных резца, резцовая кромка которых находится на центральной оси заготовки, но сформирована одним резцовым снятием. В качестве заготовок для клювовидного и срединных резцов использовались отщепы (три экз.) и пластинки (три экз.). Присутствие восьми резцовых отщепков свидетельствует в пользу подправки, а возможно, и производства резцов на месте стоянки.

В группе скоблевидных орудий (16,29\%) можно различить пластинки и отщепы с выемками на конце (11 экз.), сколы с боковыми выемками (18 экз.). Концевые скобели (вкладыши с усеченным концом?), имеющие особенно важное культурно-дифференцирующее значение, изготовлены преимущественно на пластинках (9 экз.), всего два из них - на отщепах. Помимо доминирующих изделий с одной концевой выемкой (восемь) (рис. 9, 34,36), отмечены три двойных. На большинстве изделий (шесть экз.) по краям прослежена ретушь утилизации. Она порой обрамляет выемки, с вентральной поверхности, реже с дорсальной.

Скобели с выемками, нанесенными по продольным краям, представлены преимущественно одновыемчатыми образцами (10 экз.), изготовленными на пластинках (рис. 9, 32) и отщепах (четыре экз.), а также многовыемчатыми образцами на пластинках (восемь экз., рис. 9,35, 37).

В группе проколок, сверл и разверток $(3,93 \%)$ отсутствуют морфологически устойчивые формы, образующие типы. Вторичная обработка применялась минимально. Особо следует отметить проколку на пластинке с асимметричным жалом, подправленным ретушью (рис. 9, 26), сверло, изготовленное из продольно расколотой пластинки, со следами ретуши утилизации на удлиненном, асимметрично расположенном жале (рис. 9, $27)$, обломки сверл и проколок треугольной формы (два экз.), атипичные изделия (три экз.).

Важной частью каменного инвентаря стоянки является группа рубяще-долбящих изделий $(2,25 \%)$. Три из них изготовлены из кремневых галек, одно из кварцита. Формообразование во многом определялось формой исходной заготовки, сохраняющей значительные участки галечной корки. Лезвие орудий асимметрично в профиле, сформировано двусторонней обработкой (рис.10, 2-4). Как правило, лезвие с одной стороны орудия подправлено боковым сколом, а с противоположной стороны - продольными снятиями. О периодическом подживлении лезий тесел и топориков свидетельствуют боковые подправочные сколы, встреченные в материалах стоянки $(1,12 \%)$

В коллекции присутствуют три наконечника стрел (дротиков), обработанные двусторонней ретушью. Один из них подтреугольной формы (рис. 10, 1), два других, представленных обломками, имеют листовидную форму. Если наконечник подтреугольной формы находился в начальной стадии обработки, то последние два изделия обработаны струйчатой ретушью.

Особенностью памятника является относительно небольшое количество отщепов с ретушью $(3,37 \%)$. Эти орудия обработаны фрагментарной ретушью и не имеют устойчивой формы.

Единичными экземплярами представлены в коллекции памятника атипичный микрорезец, фрагмент пластинки с усеченным ретушью концом.

Представляет интерес рассмотрение обломков глинистого ожелезненного сланца. Присутствует одно изделие (рис. 7,8) и 13 бесформенных обломков размеСамарский научный вестник. 2014. № 3(8) рами 2,4х1,5х0,7-1,3х0,6x0,5 см. Изделие имеет стержневидную, трехгранную в поперечном сечении форму. Один его конец закруглен, второй, противоположный, обломлен. На сформированных при помощи трения по абразивному материалу гранях визуально различимы однонаправленные царапины, риски, оставленные очевидно абразивом. Аналогичные поверхности встречены и на обломках. При трении таким материалом по абразиву можно получить красящий порошок красного цвета. Побочным результатом этого процесса являются следы, подобные вышеописанным. Думается, что предположение об использовании ожелезненного глинистого сланца для получения красящего вещества является достаточно обоснованным.

На поверхности стоянки были найдены два изделия из мелкозернистого песчаника. Одно из них является обломком языкоподобной формы, размерами $3,2 \times 2,7 \times 1,1$ см, с двумя продольными желобками с двух плоских сторон (рис. 7, 7). Второй обломок-конической формы, размерами 2,2х1,7x1 см. Существуют различные версии функциональной интерпретации каменных изделий с желобками, широко распространенных в материалах памятников каменного века. Использовались ли они при изготовлении костяных наконечников или для получения красящего вещества? На этот вопрос мы не можем ответить однозначно. Вкрапления краски под бинокуляром на абразивах не были обнаружены. Тема нуждается в специальном изучении.

\section{Критика источника}

Наблюдения, сделанные в процессе раскопок стоянки Орехово-Донецкое 3 за стратиграфией и планиграфией культурного слоя, изучение сырья, из которого изготовлены каменные артефакты, технико-типологический анализ каменной индустрии дает основания предполагать, что в своей массе мы имеем дело с более или менее одновременно отложившимися материалами начала неолита.

Каменная индустрия памятника (рис. 11) ориентирована преимущественно на получение пластинчатых заготовок, главным образом среднешироких и микропластинок, в том числе правильной формы. Сравнительно высок удельный вес целых пластин и низкий сечений. Среди сечений пластин велика доля удлиненных фрагментов прямоугольной формы. Использование наряду с ударной техникой скола с помощью кремневых, кварцитовых отбойников (возможно, также использовались «мягкие» отбойники), отжима сомнений не вызывает. Можно предположить применение посредников. В качестве преформ использовались, по-видимому, преимущественно нуклеусы так называемого донецкого типа на отщепах и обломках, а также гальки, раскалываемые по кругу. Применяемые технологии расщепления обусловили спектр типов сработанных нуклеусов, который включал одноплощадочные нуклеусы конической, карандашевидной и клиновидной формы. Анализ ядрищ и заготовок позволяет отметить некоторые стандартные приемы формирования ударных площадок и поверхностей расщепления ядрищ. Среди них периодическое переоформление угла площадки по отношению к поверхности скалывания мелкими снятиями или широким сколом, убирающим всю или значительную часть старой площадки; использование боковых поверхностей, граней ядрищ для выравнивания фронтальной поверхности расщепления, освобождения ее от заломов с помощью сколов, поперечных по отношению к длинной оси нуклеуса. В процессе раскалывания использовались приемы как ударного, так и отжимного расщепления.

Ведущая роль заготовок-пластинок подтверждается не только их значительным удельным весом в составе всей коллекции, но и тем фактом, что подавляющая часть изделий с вторичной обработкой изготовлены на пластинках. В группе изделий с вторичной обработкой стоянки культурно-хронологическими индикаторами являются микролиты и рубящие изделия. 
Микропластинки с притупленным ретушью краем, трапеции и тесла представлены значительными сериями Трапеции/прямоугольники выражены как экземплярами со струганой спинкой, так и с круторетушированными боковыми сторонами. Важной проблемой источниковедческого анализа является органичность присутствия трапеций/прямоугольников со струганой спинкой в данном комплексе. Три изделия со струганой спинкой, изготовленные из крупных, шириной 1,6-2 см, правильных пластин, выпадают из технологического ряда индустрии Орехово-Донецкой 3. В нем нет следов производства подобных пластин. Вместе с тем, пластинки меньшей ширины, из которых могли быть изготовлены трапеции со струганой спинкой, здесь представлены. Мы не исключаем возможности того, что данные трапеции/прямоугольники, а также наконечники стрел, изготовленные в технике двусторонней обработки, являются в более архаичном комплексе поздней, энеолитической примесью. Трапеции, обработанные крутой ретушью по боковым сторонам, включают симметричные средневысокие и высокие с прямоусеченными боковыми сторонами, а также одну с вогнутыми боковыми сторонами Тесла изготовлены из галек в технике двусторонней оббивки, имеют лезвие, сформированное боковым сколом Сколы периодической подправки лезвия служат подтверждением традиционности применения данного технологического приема. Показательны сравнительно малочисленные яниславицкие острия со сломанным основанием, ромбовидные острия, а также обломки, очевидно, асимметричных микролитических треугольников. По всей видимости, богатый и разнообразный арсенал микролитических форм предназначался для оснащения веретенообразных костяных острий, хорошо известных по материалам мезолита и неолита Северского Донца. Для определения культурной позиции памятника важны многочисленные резцы-струги на нуклевидных отщепах, а также выразительная группа изделий на пластинках с усеченным ретушью концом (концевые скобели?), несколько вкладышей кукрекского типа. Интерес представляет серия концевых скребков, количественно доминирующих по отношению к другим типам. Менее специфичны подокруглые частично ретушированные скребки на отщепах, резцы на углу слома заготовки, пластинки с краевой ретушью, пластинки с краевыми скоблевидными выемками, проколки, сверла, развертки.

Подводя итоги технолого-типологическому анализу индустрии Орехово-Донецкой стоянки, можно выделить в ней несколько культурно-исторических блоков: один из них, пара-яниславицкий, включает донецко-яниславицкие острия, обломки асимметричных треугольников и, по всей видимости, микропластинки с притупленным краем, ромбовидное острие, возможно, топорики изюмского типа. Можно с высокой вероятностью предположить функциональную сопряженность многих этих форм с веретенообразными остриями из кости с боковыми пазами и каменными абразивами с продольным желобом для заточки таких острий. Второй блок, как правило, в бассейне Северского Донца ситуативно, отчасти технологически, тесно сопряженный с первым, представляют нуклеусы донецкого типа, резцы-струги, карандашевидные нуклеусы, вкладыши с одним-двумя усеченными-выемчатыми концами, очевидно, кукрекские вкладыши. Этот блок хорошо представлен в материалах архаико-ранненеолитических слоев Каменной Могилы $[4$, рис. 7 ; 9]. Третий блок не столь репрезентативен, как в других донецких стоянках, выражен геометрическими формами, среди которых есть изделия более узкого хождения - трапеции с талией, а также транскультурные типы - трапеции/прямоугольники со струганой спинкой, средневысокие трапеции.

Набор типов орудий, характер их использования во многом определили совокупность приемов вторичной обработки. Широкое распространение получила крутая, почти отвесная краевая мелкофасеточная ретушь, полу62 крутая скребковая, полукрутая краевая. Следует отметить наличие плоской, ступенчатой и пологой ретуши. При изготовлении части острий использовалась техника «псевдомикрорезцового» скола [5, с. 89].

Место материалов Орехово-Донецкой 3 в мезолите-неолите Юга Левобережной Украины

Нам представляется, что индустрия ОреховоДонецкой 3 сформировалась в один из особых, переломных этапов развития средне-позднекаменного века на территории пограничья лесостепи и степи в междуречье Днепра и Дона. Он был ознаменован внезапным появлением большого количества культурно однородных памятников, занявших со значительной регулярностью на территории протяженностью до 300-400 км многие природные ниши, оптимальные для ведения охотничье-рыболовческой экономики. Памятники, имеющие высокий уровень сходства с Орехово-Донецкой 3 по набору орудий и характеру технологии расщепления, расположены преимущественно на Левобережье среднего течения Северского Донца, а также в бассейне нижнего течения Днепра. Южнее этого ареала, на территории Донецкого кряжа, а также в Северо-Западном Приазовье, располагались памятники с меньшим, но, по-видимому, также исторически релевантным уровнем сходства стоянкам Подонцовья. Распространение памятников, более или менее аналогичных Орехово-Донецкой 3 стоянке в Среднем Поднепровье [6;7], в бассейне Ворсклы и Сулы [8] свидетельство наличия «сильных связей» этого культурного явления в лесо-степном, лесном северозападном направлении.

Поскольку, к сожалению, мы не располагаем абсолютными датировками Орехово-Донецкой 3, можно попытаться установить предполагаемый возраст данного памятника путем сопоставлений его с материалами более или менее аналогичных стоянок. При этом мы хотели бы сделать очень важную оговорку: корпус источников по донецкому неолиту и смежным территориям в силу воздействия самых различных причин не отвечает требованиям современной науки. В силу этого все выводы, сделанные нами, следует рассматривать как предварительные.

\section{Датировка Орехово-Донеикой 3}

Важным ориентиром для определения возраста комплекса Орехово-Донецкой 3 могут служить датированные радиокарбонным методом неолитические памятники, расположенные в 8 км к югу от районного центра пгт. Кременная (Луганская область) [9, с. 31-64]. В первую очередь, речь должна идти о стоянках Зелена Горница 1 и 5, каменный инвентарь которых, вплоть до мельчайших деталей, повторяет материалы Орехово-Донецкой 3. Согласно датированию органического вещества в керамике, сопровождавшей каменную индустрию данных стоянок, они относятся к 6 тыс. calBC (Q $5880-5200$ BC) [10, с. 15]. По-видимому, этим же временем, как и предполагалось ранее при рассмотрении хронологии распространения наиболее ранних памятников с трапециями со струганой спинкой [12, с. 113], должно датироваться поселение Ольховая 5, расположенное от Орехово-Донецкой стоянки на расстоянии около 5км выше по течению Северского Донца. Материалы этого поселения по характеру кремневого инвентаря, в значительной степени облику керамики аналогичны материалам упомянутых стоянок в районе Кременной, а по облику кремневой индустрии тождественны Орехово-Донецкой 3. Для определения хронологии Орехово-Донецкой стоянки важны также параллели с близкими материалами некоторых памятников Нижнего Поднепровья, датированных по радиокарбону. Так, например, 6 тыс. calBC (5800-5500 calBC) датирован по кости комплекс стоянки Кизлевый 5 , расположенной южнее г. Днепропетровска [13, p. 50]. Он аналогичен инвентарю Орехово-Донецкой 3 в значительной части таких индикативных показателей кремневой индустрии, как технология отжимного получения пластинок и микропластинок с использованием карандашевидных нуклеусов, набору геометрических и негеометрических микролитов. Значительные

Самарский научный вестник. 2014. № 3(8) 
параллели Орехово-Донецкой 3 мы видим в инвентаре стоянки Попов Мыс, расположенной на полуострове Игрень в черте г. Днепропетровска [14, с. 145-154]. Они заметны особенно в части техники расщепления кремня, в наборе нуклеусов, включающем нуклеусы донецкого типа, ансамбле негеометрических микролитов, типологическом спектре резцов и скребков, пластин с ретушью. Керамика, собранная на поверхности этой стоянки, датируется также 6 тыс. calBC $[10$, c. 15]. Там же, на Игреньском полуострове, на поселении Игрень 8, были исследованы отдельные жилища, датированные последней четвертью 8-6 тыс. calBC [15; 16, fig. 12]. Вполне возможно, что встреченный там, например в жилищах 8 и 10, набор микролитов, характерный также для Орехово-Донецкой 3 , хотя бы отчасти относится к тому же 6 тыс. calBC. Этот набор включает донецкие острия, микролиты с притупленной спинкой, асимметричные треугольники. В северо-западной части заполнения ямы «Б» Ясиноватского могильника [17, с. 79-80] были встречены геометрические и негеометрические микролиты, аналогичные формам из Орехово-Донецкой 3 [17, рис.9: 1-11]. Погребения в этой части ямы $(17,18,19)$, основываясь на данных Оксфордской лаборатории, датируются второй половиной 6 тыс. calBC [18, p. 628, fig. 78.3]. Итак, сопоставление материалов Орехово-Донецкой стоянки 3 с комплексами, датированными по радиокарбону, позволяет датировать ee 6 тыс. calBC. Исходя из вероятности принадлежности, хотя бы части трапеций со струганой спинкой к основному инвентарю Орехово-Донецкой стоянки, мы склонны этот интервал сузить до второй половины 6 тыс. calBC.

Орехово-Донецкое 3 в периодизации Донецкой культуры

В Среднем и Нижнем Подонцовье известны два стратифицированных памятника, которые, в известной степени, позволяют определить место ОреховоДонецкой 3 в периодизации донецкого неолита. В Нижнем Подонцовье, на территории Ростовской области Российской Федерации, это многослойное поселение Нижнесеребряковское 1 [19, с. 68-83], а в Среднем Подонцовье - нижний слой поселения Устье Оскола 2 [20, с. 176-187]. Хотя в кремневом инвентаре нижнего слоя (слой 5) поселения Нижнесеребряковское 1, повидимому, в силу регионального своебразия, отсутствовали многие типы орудий, показательные для микролитического набора Донецкой культуры в Среднем Подонцовье, в частности, донецкие (яниславицкие) острия, асимметричные треугольники, тем не менее, встреченные здесь микропластинки с притупленным краем, сопровождаемые правильными отжимными микропластинками и резцами-стругами, указывают на возможность синхронизации этого комплекса с инвентарем Орехово-Донецкой 3. Керамика здесь отсутствовала. Стерильный слой отделял слой 5 от вышележащего слоя 4. В нем симптоматично появление керамики с растительной примесью, а также трапеций, обработанных крутой ретушью, и со струганой спинкой. Микропластинки с притупленной спинкой здесь сменились пластинками с краем, притупленным крутой ретушью. Заметна утрата традиции изготовления микропластинок и переход к использованию пластинок. Эта тенденция получила развитие в слое 3 .

Нижний слой поселения Устье Оскола 2, в котором была встречена керамика, топорики изюмского типа, резцы-струги, карандашевидные нуклеусы и микролиты-трапеции с круто ретушированными боками, микропластинки с притупленной спинкой, острия с косо скошенным концом, также может быть синхронизирован с материалами Орехово-Донецкой стоянки. Более развитое керамическое производство и комплекс с более крупными, хотя и правильными пластинами были установлены при раскопках верхнего неолитического слоя Устье-Оскола 2. Здесь же была найдена трапеция с начальным подстругиванием спинки. Д.Я. Телегин показал связь комлекса нижнего слоя Устья Оскола 2 с материалами расположенных по соседству неолитических Самарский научный вестник. 2014. № 3(8) поселений Бондариха 2 и Студенок 5 [20, с. 186]. Лучше опубликованный комплекс Бондарихи 2 [21] также по набору ведущих форм каменного инвентаря может быть поставлен в один ряд с материалами Орехово-Донецкой 3. В нем были встречены несколько обломков типичной для донецкой культуры керамики с травой, которая, по словам В.Н. Даниленко, является самой древней в этом районе глиняной посудой [22, с. 30].

Какие памятники донецкой культуры предшествовали появлению комплексов типа Орехово-Донецкой 3 ? По нашему мнению, наиболее определенно к более раннему периоду можно отнести материалы мезолитической стоянки хутор Шевченко [23, с. 146-160; 24]. В данном случае, мы исходим не столько из типологических оснований, сколько из стратиграфии этой стоянки, культурный слой которой, несмотря на многочисленные повреждения биотурбационными процессами, участками сохранился in situ. Он был приурочен к делювиальному темно-желтому суглинку, который, как можно заключить из заключения геолога Н.А.Сиренко, отложился не позднее раннего голоцена. Нам представляется также возможным для подкрепления данного тезиса обратить внимание на сходство топографии и стратиграфии хутора Шевченко и Каменной Могилы 1 , известной многослойной стоянки в долине реки Молочной в Приазовье, в которой архаичные, очевидно раннеголоценовые слои, были приурочены к делювиальным суглинкам [4, с. 16; 25, с. 52]. Весьма вероятно, что с хутором Шевченко синхронизируются материалы самого раннего слоя поселения Пидгоривка на р.Айдар [26, с. 15-24]. В пользу этого говорят также данные стратиграфии и характер фаунистической коллекции этого памятника. В лессовидном суглинке залегал культурный слой стоянки Райгородок, выявленный В.Н. Гладилиным на Северском Донце [27, с. 180; 28, с. 16]. По характеру кремневой индустрии он схож с комплексом хутора Шевченко. В разное время многие исследователи, обращали внимание, что некоторые технико-типологические особенности индустрии хутора Шевченко, в частности, широкое использование микрорезцовой техники при изготовлении донецких острий, дифференцированность набора микролитических изделий дают возможность синхронизировать с ним памятники без выраженной стратиграфии. Среди них стоянка Пелагеевка 3, обнаруженная в верховьях реки Айдар, стоянка Пришиб, расположенная в среднем течении р. Оскол [23, с. $158-159 ; 29$, с. 196$198 ; 6$, с. 92; 5, с. 99], еще неопубликованный комплекс стоянки Яровая 7 в Среднем Подонцовье (раскопки А.Ф. Горелика, С.М. Дегерменджи в 2005-2006 гг.). Мы разделяем мнение Е. Черныха и С. Телиженко о возможной принадлежности наиболее ранних материалов исследованной ими многослойной стоянки Заозерное 1 на Северском Донце к финальномезолитическому этапу в развитии донецкой культуры [30, с. 76]. Если датировка костей захоронения, выявленного на донецкой стоянке Клешня 3 [10, с. 143], действительно соответствует возрасту этого поселения, можно предположить, что и этот памятник относится к горизонту, который в периодизации донецкой культуры предшествует появлению стоянки Орехово-Донецкое 3. Отсутствие геометрических форм здесь, как и в Пидгоривке, отчасти в хуторе Шевченко, где в культурном слое была найдена лишь одна удлиненная трапеция, может быть аргументом в пользу раннеголоценового возраста этого памятника.

Оценить место, занимаемое стоянкой ОреховоДонецкое 3 в развитии донецкого неолита, позволяют памятники, которые относятся к периоду, непосредственно следующему за Бондарихинским. Как было отмечено выше, в 4-3 неолитических слоях Нижнесеребряковской стоянки, заготовки-микропластинки сменяются более широкими пластинчатыми заготовками-пластинками и пластинами. Технологически оправдано, что этим заготовкам соответствовали трапеции (прямоугольники) со струганой спинкой, которые были встречены в этих слоях $[19$, с. $71-77]$. В слое 4 была отмечена керамика 
с выгоревшей растительностью. Появление серий трапеций-прямоугольников со струганой спинкой на широких пластинах без крутой ретуши на боковых сторонах, известных по Устью Оскола 1 [20], Дробышево 1 [31, c. $7 ; 28$, с. 13-14], многим стоянкам побережья озера Туба [32; 10], Старобельской стоянке [33, с. 67-78], фиксирует бесспорно более поздний этап в развитии неолита. Было уже неоднократно замечено (В.Н. Даниленко, С.Н. Бибиков, А.А. Формозов, Д.Ю. Нужный,), что транскультурное по характеру распространение этих изделий отражало не только общие технологические трансформации: отмирание производства микролитических пластин и переход к использованию пластин, но и, по всей видимости, означало включение Подонцовья в систему межкультурных связей с территориями, расположенными от него к югу [34, с. 11-12], скорее всего, Предкавказья и Черноморского Побережья Кавказа, менее вероятно, Крыма. Калиброванные значения радиоуглеродных датировок памятников, в которых присутствуют наиболее ранние трапеции со струганой спинкой, несмотря на некоторый разнобой, тяготеют ко второй половине 6 тыс. calBC (рис. 12). При всей фрагментарности наших знаний о неолите Юга Восточной Европы и кустарности того научного инструментария, которым мы пользуемся, возникает впечатление, что вслед за гомогенной, в известной степени унифицированной фазой развития неолитической культуры, ассоциируемой в Подонцовье с памятниками типа Бондарихи 2, Устья Оскола 2 (нижний слой), Зеленой Горницы 1,5,6, Ольховой 2 и 5, Орехово-Донецкой 3 , Нижнесеребряковской (слой 5), приходит этап качественно иного содержания. Он характеризуется развитым керамическим производством, наличием разных стилей оформления глиняной посуды, возникновением, параллельным развитием разнотипных каменных индустрий. Эта вариабельность вуалируется распространением межкультурных типов-трендов подобным трапециям со струганой спинкой, ножам на крупных пластинах с ретушью, заходящей на спинку, скребков на отщепах. К такому выводу можно прийти, сравнивая материалы поселений Старобельск, Пидгоривка, Новоселовка на р. Айдар [33; 10], Устья Оскола 1, Устья Оскола 2 (верхний слой) [20], Серебрянское [2], Туба 1 и 2 [10], Зановское 1 [35] и т.п. В одних случаях, указанные комплексы отражают развитие традиций Бондарихинской фазы Донецкой культуры, в других (Старобельск), демонстрируют принципиально новое направление развития. Анализ этого этапа выходит за рамки целей настоящей статьи.

Итак, материалы Орехово-Донецкой стоянки, по всей видимости, датируются второй половиной 6 тыс. calBC. Очевидно, культурный слой этой стоянки отложился более или менее одновременно с многими другими памятниками Подонцовья, среди которых Зелена Горница 1 , Зелена Горница 5,6, Клешня 4, Ольховая 5 и 2, Устье Оскола (нижний слой), Лиманское озеро, Москвино [36], Бондариха 2, Студенок 5, Нижнесеребряковское 1 (слой 5), Яровая 7. Эти памятники имеют целый ряд общих черт каменной индустрии, отличаясь от стоянок более позднего времени ярко выраженным, развитым, дифференцированным набором геометрических и негеометрических микролитов, широким применением микропластин, а от более ранних мезолитических памятников появлением керамики, использованием псевдомикрорезцовой техники изготовления донецких острий, более широким использованием отщеповых заготовок для производства орудий. Как корректно дефинировать в категориях универсальной археологической периодизации каменного века Бондарихинский этап развития культуры на Северском Донце? Мезолитом или неолитом? Постановка такого вопроса отнюдь не дань археологической схоластике. Ответ на него должен в какой-то степени прояснить историческое содержание процессов, к сожалению, скудно и фрагментарно запе64 чатленных в археологической фактографии.

Мезолит или неолит?

Современный этап изучения неолита характеризуется осознанием многообразия форм и путей неолитизации. Неолитизация это не всегда и не только, как считалось ранее, переход к производящим формам хозяйствования, но и глубокие идеологические, когнитивные трансформации, смена мира символов, усложнение социальной организации, многообразие форм и способов хозяйственной деятельности [37-41]. Сложный характер неолитического общества, установленный с использованием мощного потенциала современной археологии, а также комплекса методов естественных наук в ходе изучения памятников с высокой степенью сохранности культурных остатков, вошел в противоречие с консервативным языком привычной археологической аналитики. Самое яркое проявление выхода из этого противоречия - пересмотр содержания понятия археологической культуры неолита. Сохраняющее самодовлеющую позицию в советской и постсоветской археологии, оно, в современной западной археологии неолита, утрачивает свое значение. Так, один из исследователей баденской культуры, М. Фурхолт, показал несоответствие данным современной археологии представлений, идущих от Г. Чайлда, о более или менее гомогенной культуре, в которой керамические стили связаны с определенной социальной группой со своим набором каменных орудий, погребальным обрядом, малой пластикой, единой экономической базой [42]. Проделанный им анализ керамики из 389 поселений баденской культуры показал наличие пяти стилей. Границы распространения отдельных стилей не являются дискретными. На отдельных поселениях часто присутствует керамика разных культур. Отсутствует единый тип кремневой индустрии и привязка опредленных разновидностей кремневой индустрии к определенным стилям керамики. На территории распространения баденской культуры нет единства погребального обряда и глиняной пластики. Отсутствует однородность и в развитии экономики этой культуры (в одной зоне отмечено преобладание овцы/козы, в другой - крупного рогатого скота). Политетическое представление о культуре Д. Кларка [43] больше согласовывается с подобной картиной. Мнение М.Фурхолта разделяют некоторые швейцарские коллеги, выводы которых основаны на изучении богатейших материалов неолитических свайных поселений [44, S. 209-212]. Они считают, что привычный поиск границ, разделяющих и дифференцирующих, следует поставить под сомнение, вместо поиска границ следует рассматривать только связи и контакты. В любой из периодов неолита границы и контактные области были динамичны, открыты и проницаемы. Даже соседние поселения, расположенные в одной ландшафтной нише, могут демонстрировать разные контакты с различными культурными регионами. Мы далеки от того, чтобы результаты изучения, в целом более позднего и в силу этого более сложно организованного неолитического сообщества Центральной Европы, механически переносить на понимание неолита юга Восточной Европы, но не брать их во внимание было бы ошибкой [45].

В силу плохой сохранности культурного слоя памятников среднего голоцена Юга Восточной Европы, крайне ограниченной источниковой базы в археологической практике главным критерием неолита выступает появление керамического производства. Но всегда ли появление архаичной керамики в культурном слое того или иного памятника отражает указанные выше кардинальные трансформации, знаменующие неолит?

В первой половине 6 тыс. до н.э. керамика во многих регионах Юга Восточноевропейской равнины уже не была новшеством. Значительные коллекции керамики археологическое свидетельство сформировавшегося местного керамического производства - происходят из слоев Сурской культуры в Нижнем Поднепровье, из Южного Самарский научный вестник. 2014. № 3(8) 
Побужья и Поднестровья, районов распространения БугоДнестровской культуры, из Нижнего Подонья, а также Нижнего Поволжья. В Киево-Черкасском Поднепровье, в бассейне Ворсклы под влиянием традиций самчинской фазы Буго-Днестровской культуры в 6 тыс. до н.э. возникает оригинальный стиль керамического производства [22, с. 34 ; 46 , с. $138 ; 47$, с. $28-39 ; 2$, с. 77 ; 48 , с. 33$]$. Он характеризовался использованием примитивных форм посуды со значительной примесью речного ила, орнаментированной короткими оттисками гребня, прочерченными линиями. Из этого района, а также от сурской культуры Надпорожья керамика распространяется в Подонцовье [22, с. $36 ; 49$, с. 41-42; 12, с. 111; 2, с. 77]. Археологически очевидный факт присутствия небольшого количества черепков в культурном слое большинства памятников Бондарихинской фазы развития донецкой культуры - свидетельство, очевидно, отражения конкретной исторической реальности неразвитости или отсутствия туземного керамического производства, возможного заимствования, получения керамики по различным каналам коммуникации [45, с. 127-128]. Этот феномен был отмечен на начальных этапах распространения керамики в некоторых культурах неолита [50, p. $64 ; 51$, S. 25; 52, p. 78]. Нужно отметить, что далеко не все исследователи неолита Подонцовья разделяют такое объяснение. После того как керамика с богатой примесью травы (ила) была выявлена в значительном количестве в культурном слое некоторых поселений возле озера Туба, отмеченных также известным своеобразием кремневой индустрии, был сделан вывод, что присутствие этой керамики где-либо еще за пределами Тубы - свидетельство «тубинских» примесей [10]. По мнению C.Н. Телиженко, архаичная керамика с травой, а также трапеции со струганой спинкой, найденные на стоянках Подонцовья с мезолитическим обликом кремневого инвентаря (в качестве примера взяты стоянки Зелена Горница 1,5,6, Ольховая 2 и 5), являются поздней механической примесью [53, с. 186]. В силу этого указанные стоянки следует считать мезолитическими. При всей внешней логичности такой гипотезы с ней трудно согласиться. В пользу органичной связи кремневых индустрий мезолитического облика и сопровождающей их керамики с примесью травы (речного ила) говорит распространенность этого феномена в десятке случаев во всем бассейне среднего течения Северского Донца ${ }^{1}$, тогда как каменные индустрии типа Тубинского озера за пределами этого района неизвестны. Уже многочисленная неолитическая керамика поселения Серебрянское, в том числе и с примесью травы, остродонная, непрофилированная, орнаментировання оттисками гребня и прочерченными линиями, сопровождалась иной кремневой индустрией, нежели в Тубе 1 и 2 [2]. В ней нет геометрии, анкошейлекал, нуклеусов с широкой поверхностью скалывания и правильно пластинчатым огранением, которые определяют специфику Тубы 1 и 2. Одновременно, кремневая индустрия Серебрянского значительно отличается от инвентаря стоянок Бондарихинского этапа. Архаичная керамика с травой, характерная для Тубы 1 и 2, отчасти Серебрянского поселения, распространена в КиевскоЧеркасском Полесье, в Лесостепном Поднепровье, где она сопровождается кремневым инвентарем, отличным от индустрий стоянок озера Тубы и Серебрянского поселения $[46 ; 7 ; 8]$. Если исходить из того, что «тубинцы» оставляли свою керамику на поселениях типа Ольховой 5, возникает закономерный вопрос, почему только керамику или трапеции со струганой спинкой, почему, например, не характерные для Тубы 1 и 2 анкоши-лекала? Хотя мы надеемся, что когда-нибудь будут получены более надежные археологические данные по рассматриваему вопросу, нельзя сбрасывать со счетов тех фактов, которые нам уже известны. Например, факт наличия фрагмента керамики с растительной примесью в хорошо сохранившемся слое стоянки Старица 18, в кремневом комплексе которой имеются и микролиты, включая острие яниславицкого типа [54, с. 118-129], присутствие отдельных Самарский научный вестник. 2014. № 3(8) фрагментов подобной керамики в культурном слое стоянки Яровая 7, исследованной с применением современных методов раскопок (работы А.Ф.Горелика, С.М. Дегерменджи), наличие такой керамики в относительно хорошо сохранившемся слое стоянки Бондариха 2 [21]. Иными словами, мы склонны считать керамику в материалах стоянок Бондарихинского горизонта следствием знакомства населения этих стоянок с глиняной посудой, которая могла сюда проникать различными путями, главным образом, от соседей $[55 ; 22 ; 45]$. Вместе с тем, по всей видимости, на этом этапе местное производство глиняной посуды не было еще налажено. Не исключено, что хотя бы отчасти трапеции со струганой спинкой были не только механической примесью, но могли, как и керамика, быть частью импорта. Очевидно, на начальном этапе неолита днепро-донецкая керамика, также как, например, и ранненеолитическая керамика Южной Греции [56, р. 188], выступала символом контактов различных групп населения, а не средством демаркации границ между ними.

У нас нет никаких данных, которые дают основание говорить о знакомстве населения донецкой культуры на ее Бондарихинском этапе с производящим хозяйством. С одной стороны, информативные возможности источников, которыми мы располагаем, крайне ограниченны. С другой стороны, даже на порядок более развитое, более оседлое население соседних районов - Нижнего Подонья, Побужья, Нижнего Поднепровья, по всей видимости, делало лишь первые шаги в части освоения скотоводства [55; $57 ; 58 ; 59$, с. 239; 60]. Материалы неолита Подонцовья позволяют уверенно говорить о развитии комбинированной формы хозяйствования, включающей охоту, рыболовство, речное собирательство [61; 62]. За пределами наших познавательных возможностей находится потенциально большая сфера собирательства и культивирования дикорастущих растений, которая по опыту изучения других культур мезолита и неолита играла большую роль. Оставалось ли население донецкой культуры на Бондарихинском этапе еще мезолитическим? Ответ на этот вопрос далек от однозначности. Нам представляется, что анализ пространственной организации памятников Бондарихинского этапа проливает свет на его решение.

\section{Осевой момент}

Только начиная с рассматриваемого Бондарихинского этапа, впервые в реконструируемом развитии каменного века юга Левобережной Украины, археологические памятники размещаются в географическом пространстве с такой значительной плотностью и со столь регулярной конфигурацией $[45$, с. 128]. Мы насчитали в долине Северского Донца до 15 микрорегионов, к которым приурочены либо отдельные стоянки, либо их группы (рис. 1). С юго-востока на северо-запад это 1) Усть-Донецкая группа; 2) Петровская (Луганская); 3) Орехово-Донецкая; 4) Муратовская; 5) Тубинская; 6) Кременская; 7) Лиманская (район с. Дроновки); 8) Ильичевская; 9) Зливкинская; 10) Яровская; 11) Святогорская; 12) Усть-Оскольская; 13) Бондарихинская (Изюмская); 14) Берецкая (бассейн реки Берека); 15) Среднеоскольская. Почти все из них расположены в развитой (широкой, террасированной), богатой пойменными озерами и соответственно растительным и животным миром, Левобережной части Северского Донца, в значительной близости от источников кремня в меловых отложениях или галечниковых россыпях на его Правобережье.

Мы исходим из того, что археологический контекст, выраженный памятниками определенного типа, набором структур, а также артефактов, может служить, в известной степени, путем к изучению связей первобытных коллективов, характера их самоидентификации, определения интенсивности взаимодействия, а также установления возможных границ. Рассматриваемые памятники Подонцовья представлены остатками временных, сезонных стоянок теплого периода времени года, занимавши- 
ми относительно небольшую площадь (до 200 кв.м), вероятно, с легкими жилищами. Следы жилищ, очагов и прочих элементов, связанных с долговременным пребыванием человека, здесь редки. Порой высокая насыщенность слоя находками, по-видимому, была обусловлена накоплением материалов вследствие ритмических посещений на протяжении длительного времени. По многим указанным параметрам (наличие жилищ, долговременных структур, приспособлений) Подонцовье значительно отличается от приблизительно синхронных, соседних поселений Нижнего Подонья $[57 ; 58 ; 63 ; 60]$. Этот факт, по-видимому, не случаен, так как он корреспондируется со значительными различиями в типологии находок. Если с соседями на востоке, юго-востоке (стоянки платовоставской, ракушечноярской культур) памятники Бондарихинского этапа имели мало общего, то их сходство по технико-типологическим особенностям каменного инвентаря между собой было высоким (рис. 13). Мь исходим из гипотезы, что высокая степень интегрированности материалов различных памятников, особенно разделенных сотнями километров, отражает большую интенсивность исторических связей населения, которое их оставило. В пользу правомерности формулировки этой гипотезы свидетельствует зачастую высокий уровень сходства стоянок, расположенных по соседству. Есть различные способы оценки уровня интегрированности того или иного массива археологических данных. Выбор соответствующего научного инструментария обусловлен характером источников, степенью их изученности и введения в научный оборот, целями исследования и применяемой научной методологией. Мы избрали путь составления таблицы сериации, на основе 80 типов изделий и параметров каменных индустрий из 10 памятников условно Бондарихинского этапа, расположенных не только в Подонцовье, но и в смежных регионах- Донецкого кряжа, Надпорожья и Северо-Западного Приазовья (рис. 13, 1-3). Среди избранных типов и параметров мы различаем ведущие или определяющие банальные, транскультурные и индивидуальные. К первой категории мы относим типы, параметры, которые отличаются устойчивостью (они постоянно присутствуют в инвентаре референтной группы памятников), находятся в значительной технологической или функциональной сопряженности с другими элементами (часть пучка взаимосвязанных элементов), имеют выраженную территориальность (распространены в рамках определенного региона). К числу банальных относятся параметры (типы изделий), не обнаруживающие специфической модели (паттерна) пространственного и временного распространения (например, резцы на углу слома или скребки на отщепах). Транскультурными являются изделия, типы, формы (например, трапеции со струганой спинкой), которые распространяются в ограниченное время на территории нескольких культур, не имеющих близкой взаимосвязи. Индивидуальны изделия, типы, встреченные единично, в отрыве от массива от технологической или функциональной внутренней логики комплекса. Характеристика типов, отнесение их к определенной категории не абсолютна, зависит от данного пространственно-временного контекста. Анализ сериации ведущих типов и параметров в данной таблице может быть интегрирован в двух категориях: 1. Сквозного сходства; 2. Нарастающей типологической вариативности. Сквозное сходство объединяет комплексы ряда рассматриваемых памятников среднего течения Северского Донца. Нарастающая вариативность имеет место при сравнении каменного инвентаря памятников Подонцовья с индустриями Донецкого кряжа, Надпорожья и Западного Приазовья. Сравнительный анализ материалов пяти достаточно репрезентативных стоянок Северского Донца: Орехово-Донецкой 3 , Ольховой 5 , Зеленой Горницы 1 , Яровой 7, Бондарихи 2 показал, что вне зависимости от расстояния между ними (карта) эти стоянки демонстрируют не только обшие чер66 ты адаптации к лесостепному ландшафту Подонцовья, но и сходный набор ведущих, определяющих типов, признаков в орудийном инвентаре. К их числу мы относим наличие дифференцированных блоков геометрических и негеометрических микролитов, включая острия донецко-яниславицкого типа, симметричные трапеции с талией, большие серии микропластинок с притупленным краем, усеченными концами (рис. 13, 1-3; 14). Показательно наличие топориков-тесел изюмского типа с характерными сколами боковой подправки, нуклеусов донецкого типа, сопряженных с резцами с ретушированной выемкой между двумя резцовыми гранями и боковыми резцами на отщепах с плоскими сколами, заходящими на вентральную плоскость, а также единичных нетипичных вкладышей кукрекского типа, с похожими на них пластинчатыми вкладышами с одной-двумя ретушированными выемками на концах. Большинство из указанных типов находятся в технологической, функциональной сопряженности. Можно предположить, что распространение в Днепро-Донецком регионе веретенообразных наконечников из кости с одним-двумя пазами (подобно находкам в Ольховой 5, Райгородке, Изюме, Харькове и т.д.), вызвало к жизни оснащение из микропластинок с притупленным краем, распространение техники отжима, нацеленной на производство микропластин, с нуклеусами донецкого типа, карандашевидными, пирамидальными нуклеусами как остаточных форм. По-видимому, повсеместно встреченные плиткиабразивы с продольным желобом, возможно, служившие для изготовления таких костяных острий, являются еще одним идентификационным признаком донецкого мезо-неолита. Индивидуальные формы представлены, например, иволистными наконечниками на пластинках с постсвидерским характером ретуши. Обращают на себя внимание границы распространения указанного орудийного набора. В Подонцовье граница проходит по долине Северского Донца между г. Изюмом в Харьковской области и г. Луганском. Севернее долины Донца этот набор встречается изредка в бассейне рек, впадающих в Северский Донец (Оскол, Айдар), но не далее к северу. На Правобережье Донца, в Донецком кряже, в классической степной зоне, приблизительно синхронные памятники Моспинской группы (Моспино, Минчекур, Кременная гора, Дружковка) содержат отчасти сходный, но уже значительно редуцированный набор ведущих форм орудий (рис. 13, $1-3 ; 14)$. В нем единичны микропластинки с притупленным краем, нет асимметричных треугольников и отсутствуют донецко-яниславицкие острия, низкие трапеции, сегменты. В этих памятниках керамика не обнаружена. Сравнение памятников Подонцовья с синхронными стоянками Нижнего Поднепровья и Северо-Западного Приазовья интересно в двух отношениях. С одной стороны, мы отмечаем наличие многих черт сходства между памятниками, расположенными в лесостепи, особенно яркие примеры параллелей индустрии Подонцовья в инвентаре надпорожских стоянок Попова Мыса и Кизлевого 5. С другой стороны, имеет место сокращение перечня общих с Подонцовьем ведущих типов с памятниками, расположенными к югу, в степной зоне (Каменная Могила) (рис. 13, 1-3). Интересно, что для этого района характерны т.н. утюжки, выпрямители древков стрел с поперечным, а не продольным желобом. Наиболее отчетливые отличия индустрии Подонцовья при сравнении с памятниками Приазовья и Нижнего Поднепровья заключаются в отсутствии здесь овальных топориков, наличии менее типологически дифференцированного набора геометрических форм, которых в Каменной Могиле почти нет, вместе с тем и в Нижнем Поднепровье и Приазовье широко представлены кукрекские вкладыши и резцы, причем в классических для Кукрека формах, почти не известных в Подонцовье, также стамесковидные орудия, миниатюрные скребки кизлевського типа.

Самарский научный вестник. 2014. № 3(8) 
Попытаемся теперь сугубо археологический сравнительный дискриптивный анализ перевести на язык исторического описания. Внезапное появление в значительной части Среднего Подонцовья многочисленных стоянок, установленный нами сквозной характер сходства материалов памятников Бондарихинской фазы Подонцовья может свидетельствовать о значительном демографическом скачке по сравнению с предшествующим мезолитическим периодом. Такой стремительный рост населения мог быть вызван позитивными для роста биологических предпосылок жизни климатическими изменениями, в частности воздействиями продолжительного потепления [64], наступившего после т.н. 8.200 calBP эффекта, резкого похолодания и увлажнения, широко обсуждаемого в последнее время в научной литературе [65]. Вызванная развитием рыболовства сезонная оседлость должна была привести к снижению мобильности по сравнению с поздним палеолитом и мезолитом. В силу этого наступившая, ясно прослеженная сквозная стилевая гомогенность материальной культуры может быть индикатором укрепления социальных связей, более интенсивных контактов, наличия значительной интеграции населения внутри данной территории $[67$, р.259; 68, S. 83]. Распространение определенных типов изделий (донецко-яниславицких острий, каменных плиток с продольным желобом, микропластинок с притупленным краем) на строго ограниченной географическими барьерами территории может свидетельствовать об их более высокой роли в самоидентификации населения Подонцовья, нежели других изделий. Можно предположить, что такой жесткий характер распространения определенных типов изделий связан с возникновением известной сакрализации территории, нового уровня идеологической зрелости, которой не было в мезолите. С большой долей осторожности, мы предлагаем видеть за этими явлениями усложнение социальных связей, мировоззрения, что может рассматриваться как черта постепенной неолитизации, пролога к восприятию доместикации.

На наличие связей населения Подонцовья с другими территориями указывает распространение некоторых ведущих форм (микропластинок с притупленным краем, с усеченными концами, донецко-яниславицких острий, веретенообразных наконечников с боковым пазом), например, в Надпорожье. На фоне того, что эти знаковые изделия не известны на территории Донецкого Кряжа, указанный факт может расцениваться как сигнал более высокого статуса связей населения Подонцовья и лесостепной части Нижнего Поднепровья, их значительной степени родственности. Распространение указанных форм вверх по Днепру, в Среднее Поднепровье, технологическое и орнаментальное сходство керамики Киево-Черкасского Поднепровья и Подонцовья являются еще одним подтверждением важности этого направления связей. Вместе с тем, и на Донце, и в Приазовье, например в Каменной могиле, и в Нижнем Поднепровье, мы видим следы еще одного эпизода, по-видимому, получившего развитие до появления памятников Бондарихинской фазы. Его документируют распространение техники отжимного расщепления с использованием одноплощадочных округлоконических, пирамидальных, карандашевидных нуклеусов, нуклеусов донецкого типа, что может найти объяснение в принадлежности этих территорий в конце плейстоцена к единому эпиграветтскому массиву. Показательно, что хотя следы взаимосвязей с Подонцовьем в индустрии Раздольной 2, в Матвеевом Кургане, в Платовоставской культуре ничтожны, Нижнее Подонье, как и Подонцовье, Нижнее Поднепровье, вплоть до Побужья в западном направлении в конце Бондарихинской фазы пережило сильный импульс, направленный с юго-востока, с территорий Причерноморского побережья Кавказа, возможно, Крыма. С этим импульсом, отмеченным транскультурным по своему характеру распространением трапеции Самарский научный вестник. 2014. № 3(8) со струганой спинкой, мог быть связан распад описанного единства, начало новой страницы в истории местного неолита.

\section{СПИСОК ЛИТЕРАТУРЫ}

1. Гей А.Н. Самсоновское многослойное поселение на Дону // Советская археология. 1979. №3. С. 119-131.

2. Санжаров С.Н., Бритюк А.А., Котова Н.С., Черных Е.А. Поселения неолита - ранней бронзы Северского Донца. Луганск: ВНУ, 2000. 127 с.

3. Коваль Ю.Г., Горелик А.Ф. Резцы, струги или нуклеусы? К вопросу о назначении одного из специфических изделий в индустриях каменного века Донбасса // Археологический альманах. Донецк, 2008. Вып. 19. С. 263-274.

4. Даниленко В.Н. Кам`яна Могила. К.: Наукова думка, $1986.151 \mathrm{c}$.

5. Нужний Д.Ю. Розвиток мікролітичноі техніки в кам' яному віці: удосконалення зброі первісних мисливців (видання друге, доповнене). К.: Видавництво КНТ, 2007. 306c.

6. Залізняк Л.Л. Фінальний палеоліт і мезоліт континентальноі Украіни. К.: Шлях, 2005. 184c.

7. Залізняк Л.Л. Мезоліт Заходу Східноі Европи // Кам`яна доба Украіни. К.: Шлях, 2009, Вип. 12. 278c.

8. Гаскевич Д.Л., Гавриленко І.М. До походження Дніпро-Донецького неоліту Лісостепового Подніпров ' я // Археологія. 2000, №1. С. 81-91.

9. Манько В.А., Телиженко С.А. Проблемы абсолютной хронологии мезолита-энеолита Подонечья // Материалы и исследования по археологии Восточной Украины. Луганск, 2003. Т. 1. С. 31-64.

10. Манько В.О. Неоліт Південно-Східноі Украіни. Киів: Шлях, 2006. 280с.

11. Горелик А.Ф. Рецензия. В.О. Манько. Неоліт Південно-Східноі Украіни. Навчальне видання. Киів: Шлях, 2006 // Археологические записки. Ростов-наДону, 2009. Вып. 6. С. 315-326.

12. Горелик А.Ф., Выборный В.Ю. Итоговые результаты исследований неолитических памятников в устье p. Ольховой // Археологический альманах. Донецк. 1995. Вып. 4. С. 105-126.

13.Kotova N., Tuboltsev O. The neolithic site Kizlevy 5 in the Dnieper Rapids Region (Ukraine). Atti Soc. Preist. Protost. Friuli-V.G., Trieste, 2010-2011 (2013), XVIII. P. 33-52.

14.Нужный Д.Ю. О своеобразии памятников кукрекской культурной традиции в Днепровском Надпорожье // Каменный век: памятники, методика, проблемы. Сборник научных трудов. Киев: Наукова думка, 1989. C. $145-154$.

15. Телегін Д.Я. Ігренське поселення на Подніпров ` та проблема житлобудування в мезоліті Східноі Европи. Луганськ: Шлях, 2002.91c.

16. Biagi P., Kiosak D. The Mesolithic of the northwestern Pontic region. New AMS dates for the origin and spread of the blade and trapeze industries in south eastern Europe. Eurasia Antiqua. 2010. N 16. P. 21-41.

17. Телегин Д.Я. Неолитические могильники мариупольского типа. Киев: Наукова думка, 1991. 95с.

18. Lillie M. Late Mesolithic to Early Neolithic communities in the Dnieper Rapids region of Ukraine: chronology and socio-economic continuity? // Mesolithic on the Move/ Ed. by Larsson L. Oxford. 2003. P. 625-632.

19. Цыбрий В.В. Материалы неолита, энеолита и поздней бронзы поселения Нижнесеребряковское 1 в низовьях Северского Донца // Археологические записки. Ростов-на-Дону, 2002. Вып. 2. С. 68-83.

20. Телегин Д.Я. Раскопки неолитических стоянок в устье р. Оскола // Материалы и исследования по археологии СССР, 1979. М.-Л., 1960. С. 176-187.

21. Телегін Д.Я. Неолітична стоянка в ур. Бондариха // Археологія. Т. IX. Киев, 1954. С. 158-167.

22. Даниленко В.Н. Неолит Украины. Главы древней 
истории Юго-Восточной Европы. Киев: Наукова думка, 1969. 260c.

23. Горелик А.Ф. Новые мезолитические памятники с яниславицкими вкладышевыми элементами на Северском Донце // Советская археология. М., 1987. № 3. С. $146-160$.

24. Горелик А.Ф. Памятники РогаликскоПередельского района. Проблемы финального палеолита Юго-Восточной Европы. Киев-Луганск: РИО ЛИВД, 2001. 366c.

25. Гаскевич Д.Л. Поселение Каменная Могила 1 и начало неолитизации Северного Причерноморья: гипотезы, аргументы, факты // Stratum plus. Кишинев, 2012. № 2. C. $45-65$.

26. Горелик А.Ф. Нижний слой Подгоровского поселения на p. Айдар // Матеріали та дослідження 3 археологіi Східноі Украіни. Вып. 5. Луганськ: Вид-во СНУ імені Володимира Даля, 2006. С. 15-24.

27. Телегін Д.Я. Мезолітичні пам` ятки Украіни (IXVI тисячоліття до н.е.). Киев: Наукова думка, 1982. 243c.

28. Горелик А.Ф. Мезолит Северо-Восточного Причерноморья (вопросы культурно-хронологического членения) // Материалы каменного века на территории Украины. Киев: Наукова думка, 1984. С. 4-23.

29. Залізняк Л.Л. Передісторія Украіни Х-У тис. до н.е. Киев: Бібліотека Украінця, 1998. 305 с.

30. Черних Е.О., Теліженко С.А. Матеріали пізнього мезоліту - ранньоі бронзи поселення Заозерне 1 на Сіверському Дінці // Матеріали та дослідження 3 археологіi Східноі Украіни. Луганськ: Вид-во СНУ імені Володимира Даля, 2011. Вип. 11. С. 18-79.

31. Сібільов М.В. Старовинності Ізюмщини. Вип. II. Ізюм, 1926.

32. Сібільов М.В. Матеріали до вивчення післяпалеолітичних стоянок басейну р. Донець, частина 1. Науковий архів Інститута археологіі НАН Украіни. Киів 1946- Ф 12 N 151.

33. Гурин Ю.Г. Памятники раннего энеолита бассейна Северского Донца. Луганск: Осирис, 1998. 160с.

34. Горелик А.Ф. Мезолит бассейна Северского Донца и Северо-Восточного Приазовья. Автореферат дис. канд. ист. наук. Л., 1986. 16с.

35. Телиженко С.А. Предварительные итоги исследований на многослойном памятнике Зановское 1 в 2002 году // Археологические записки. Вып. 3. Ростов-Дон: РРОО «Донское археологическое общество», 2003. С. 177-182.

36. Дегерменджи C.M. Неолитические памятники Донбасса // Тезисы Докладов областного научно-практического семинара «Проблемы охраны и исследования памятников археологии в Донбассе». Донецк, 1989. С. 14-18.

37. Cauvin J. The Birth of the Gods and the Origins of Agriculture. Cambridge: Cambridge University Press, 2000. 255 p.

38. Özdogan M. The expansion of the neolithic way of life: What we know and what we do not know? // How did farming reached Europe? /Ed. Cl. Lichter. Istanbul, 2005. P. 13-27.

39. Hauptmann H., Özdogan M. Die Neolithische Revolution in Anatolien // Vor 12.000 Jahren in Anatolien. Die ältesten Monumente der Menschheit/ Hrsg. Cl. Lichter, Karlsruhe, 2007. S. 26-36.

40. Zeder M. A. The Neolithic Macro-®Evolution: Macroevolutionary Theory and the Study of Culture Change // Journal of Archaeological Research. 2009, N 17. P. 1-63.

41. Verhoeven M. The Birth of Concept and the Origins of the Neolithic: A History of Prehistoric Farmers in the Near East // Paleorient. 2011. Vol 37.1. P. 75-87.

42. Furholt M. Pottery, cultures, people? The European Baden material re-examined // Antiquity. 2008.V. 82. P. 617-628.

43. Clarke D.L. Analytical archaeology. 2nd edition. London, 1978. 526p.

44. Doppler T., Ebersbach R. Grenzenlose Jungsteinzeit? Betrachtungen zur kulturellen Heterogenität im schweizerischen Neolithikum-ein Projektbericht // Grenzen und Grenzräume? Beispiele aus Neolithikum und Bronzezeit. Fokus /Hrsg.T. Doppler, B. Ramminger und D. Schimmelpfennig, Band 2, Kerpen-Loogh, 2011. S. 205-216.

45. Горелик А.Ф. Сложение донецкой культуры и некоторые методологические проблемы «неолитизации» мезолитических культур // Археология и этнология Восточной Европы. Одесса: ОГУ, 1997. С. 123-132.

46. Неприна В.И. Тетеревское поселение ДнепроДонецкой культуры // Советская археология. М., 1969. № 2. С. 134-139.

47. Титова Е.Н. О контактах населения киево-черкасской и буго-днестровской культур // Каменный век на территории Украины. Некоторые аспекты хозяйства и этнокультурных связей. Сборник научных трудов. Киев: Наукова думка, 1990. С. 28-39.

48. Котова Н.С. Неолитизация Украины. Луганск: Шлях, 2002. 267c

49. Телегин Д.Я. К вопросу о территории распространения памятников сурской культуры // Материалы каменного века на территории Украины. Киев: Наукова думка, 1984. С. 36-43.

50. Nishiaki Y.and Le Miere M. The oldest Pottery Neolithic of Upper Mesopotamia: new evidence from Tell Seker Al-Aheimar, the Khabur. Northeast Syria // Paleorient. 2005. Vol. 31/2. P. 55-68.

51. Özdogan M. An Anatolian Perspective on the Neolithization Process in the Balkans. New Questions, New Prospects // Beginnings-new research in the appearance of the neolithic between Northwest Anatolia and the Carpathian basin /Ed. R. Krauß. Istanbul, 2009. P. 23-33.

52. Nieuwenhuyse O.P., Akkermans P.M.M.G., van der Plicht J. Not so coarse, nor always plain- the earliest pottery of Syria // Antiquity. 2010. March. V.84, N.323. P. 71-85.

53. Теліженко С.А. Пізній мезоліт чи неоліт? До питання неолітізаціі середньоі течіi басейну Сіверського Дінця // Кам`яна доба Украіни. К.: Шлях, 2011. Вип. 14. C. $182-188$.

54. Горелик А.Ф., Дегерменджи С.М., Разумов С.Н. Старица ХУШ-новая неолитическая стоянка в Среднем Подонцовье // Археологический альманах. Донецк: Донецкий областной краеведческий музей, 2006. Вып. 18. С. $118-129$.

55. Телегін Д.Я. Дніпро-Донецька культура. До історіі населення епохи неоліту-раннього металу Півдня Східноі Европи. К.: Наукова думка, 1968. 259c.

56. Alam-Stern E. The early Neolithic Settlement in Central and Southern Greece. The actual state of research // How did farming reached Europe? Ed. Cl. Lichter. Istanbul, 2005, 83-194.

57. Крижевская Л.Я. Начало неолита в степях Северного Причерноморья. СПб, 1992 (1991). 177с.

58. Белановская Т.Д. Из древнейшего прошлого Нижнего Подонья. СПб.: Изд-во СПб Университета, 1995. 199c.

59. Товкайло М.Т. До проблеми датування БугоДністровського неоліту // Кам' яна доба Укріни. К.: Шлях, 2004. Вип. 5. С. 236-246.

60. Горелик А., Цыбрий А., Цыбрий В., Бенеке Н. Проблемы экономико-археологического анализа материалов неолитического поселения Ракушечный Яр и синхронных поселений Приазовья. Ростов-на-Дону, 2013. В печати.

61. Горелік О.Ф. Рибальскі грузила 3 поселення Ольхова 5 на Сіверьскому Дінці // Археологія. К., 1991. № 4. C. 73-76.

62. Мотузайте-Матазевичюте Г., Телиженко С.А. Керамика и земледелие или только керамика? Особенности неолита бассейна Северского Донца (по материалам неолитических поселений Восточной Украины Старобельск 1 и Новоселовка III) // Взаимодействие и хронология культур мезолита и неолита Восточной Европы. Материалы научной конференции, посвященной 100-летию Н.Н. Гуриной. СПб., 2009. С. 143-146.

63. Цыбрий В.В. Неолит Нижнего Дона и СевероВосточного Приазовья. Ростов-на-Дону: РРОО «Донское Самарский научный вестник. 2014. № 3(8) 
А.Ф. Горелик, А.В. Цыбрий СТОЯНКА ОРЕХОВО-ДОНЕЦКОЕ 3 В СРЕДНЕМ ПОДОНЦОВЬЕ ...

археологическое общество», 2008. 205с.

64. Дегерменджи С.М., Дубовская О.Р. Раскопки и разведки в Донецкой области // АО 1986. М., 1988. С. 273-275.

65. Борисова О.К. Результаты палинологических исследований разреза Ракушечный Яр-2009 // Археологические записки. Ростов-Дон: РРОО «Донское археологическое общество», 2011. Вып. 7. С. 5-14.

66. Budja M. The 8200 calBP "climate event" and the process of neolithisation in south-eastern Europe. Documenta Praehistorica. 2007. XXXIV .P. 191-201.

67. Wiessner P. Style and Social Information in Kalahari San Projectile Points // American Antiquity, Vol. 48, No. 2. Apr., 1983. P. 253-276.

68. Zeeb-Lanz A. Überlegungen zu Sozialaspekten keramischer Gruppen. Beispiele aus dem Neolithikum Südwestdeutschlands // Soziale Gruppen-Kulturelle Grenzen.
Die Interpretation sozialer Identitäten in der Prähistorischen Archäologie. Hrsg. St. Burmeister\&N.Müller-Scheeßel. Tübinger Archäologische Taschenbücher, Band 5 Münster/ New York/München/Berlin, 2006. S. 81-102.

69. Benecke N. Zur Datierung der Faunensequenz am Abri Šan-Koba (Krim, Ukraine)// Beiträge zur Archäozoologie und Prähistorischen Anthropologie. 2006. Band V. S. 12-15.

70. Сапожников И.В., Сапожникова Г.В. Каменный век Северо-Западного Причерноморья // Stratum plus. Кишинев, 2011. N 1. C. $15-331$.

71. Белановская Т.Д., Тимофеев В.И. Многослойное поселение Ракушечный Яр (Нижнее Подонье) и проблемы неолитизации Восточной Европы // Неолит-энеолит Юга и неолит Севера Восточной Европы (новые материалы, исследования, проблемы неолитизации регионов). СПб., 2003. C. $14-21$.

\section{ИЛЛЮСТРАЦИИ}

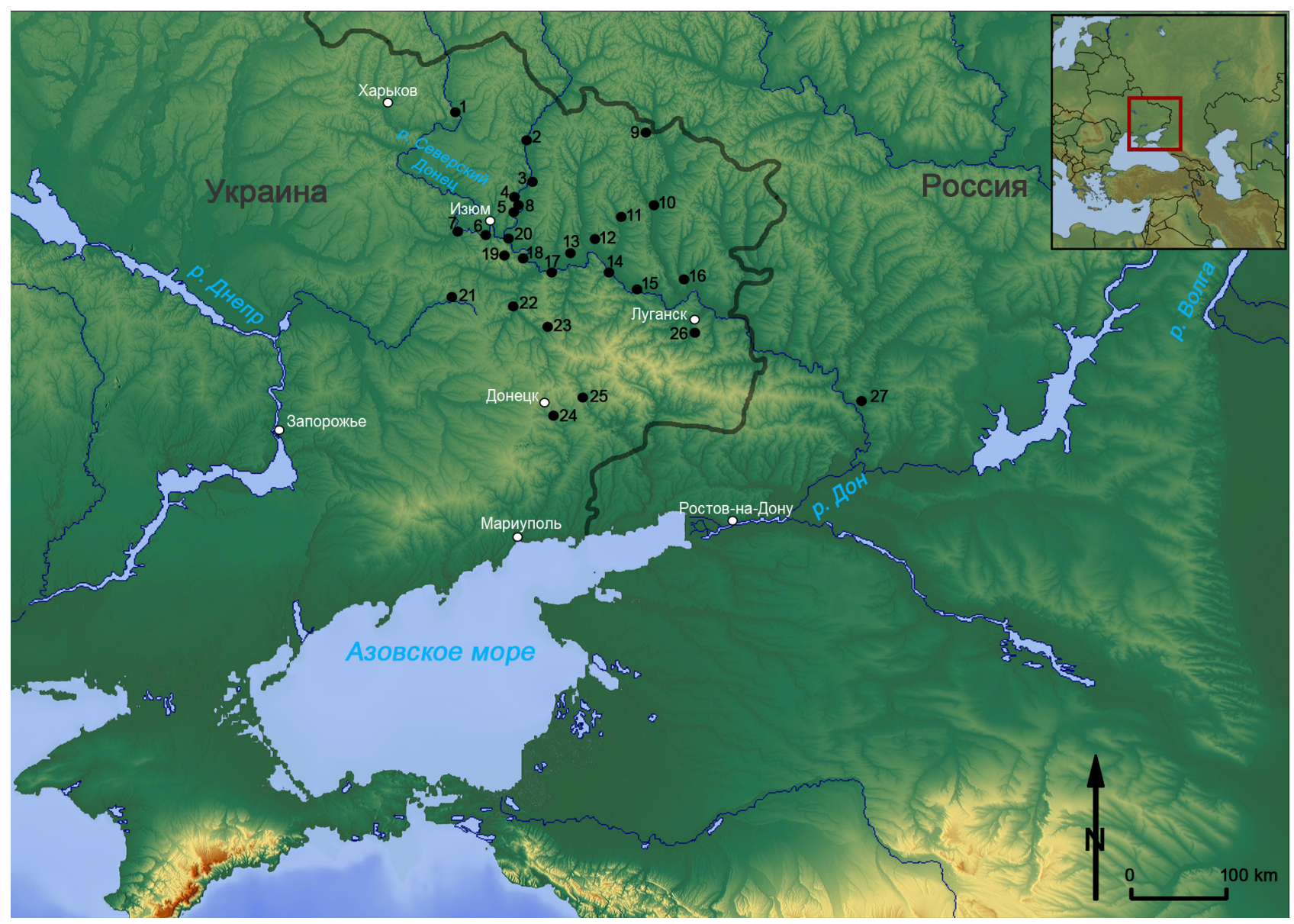

Рис. 1. Карта памятников Бондарихинского этапа Донецикой культуры и синхронных стоянок в нижнем течении Днепро-Донского междуречья (1 - Кицевка; 2 -Петрово-Орловская; 3 - Александрия; 4 - Рубиьл; 5 Устье Оскола, Яремовка; 6 - Бондариха 2, Букринские стоянки, Изюм 4а, Викличевские стоянки; 7 - Грушеваха 1, Петровские 4, 10, 28; 8-Пришиб; 9 - Пелагеевка 3; 10 - Подгоровка, Новоселовка, Старобельская; 11 Хутор Шевченко; 12 - Зеленая Горнииа 1-6, Клешня 1-5, Заозерное; 13 - Серебрянское; 14 - Туба 1-6, Зановское; 15 - Орехово-Донеикое 3, Ольховская 2, 5; 16 -Петровка-Песчаный, Кундрюикая, Теплая; 17 -Лиманское Озеро 1; 18 - Райгородок; 19 - Богородичное; 20 - Яровая 7; 21 - Кремневая Гора; 22 - Дружовка; 23 - Белая Гора; 24 - Моспино; 25 - Водобуд; 26 - стоянки у с. Менчекур; 27 - Усть-Быстрая, Нижнесеребряковская) 


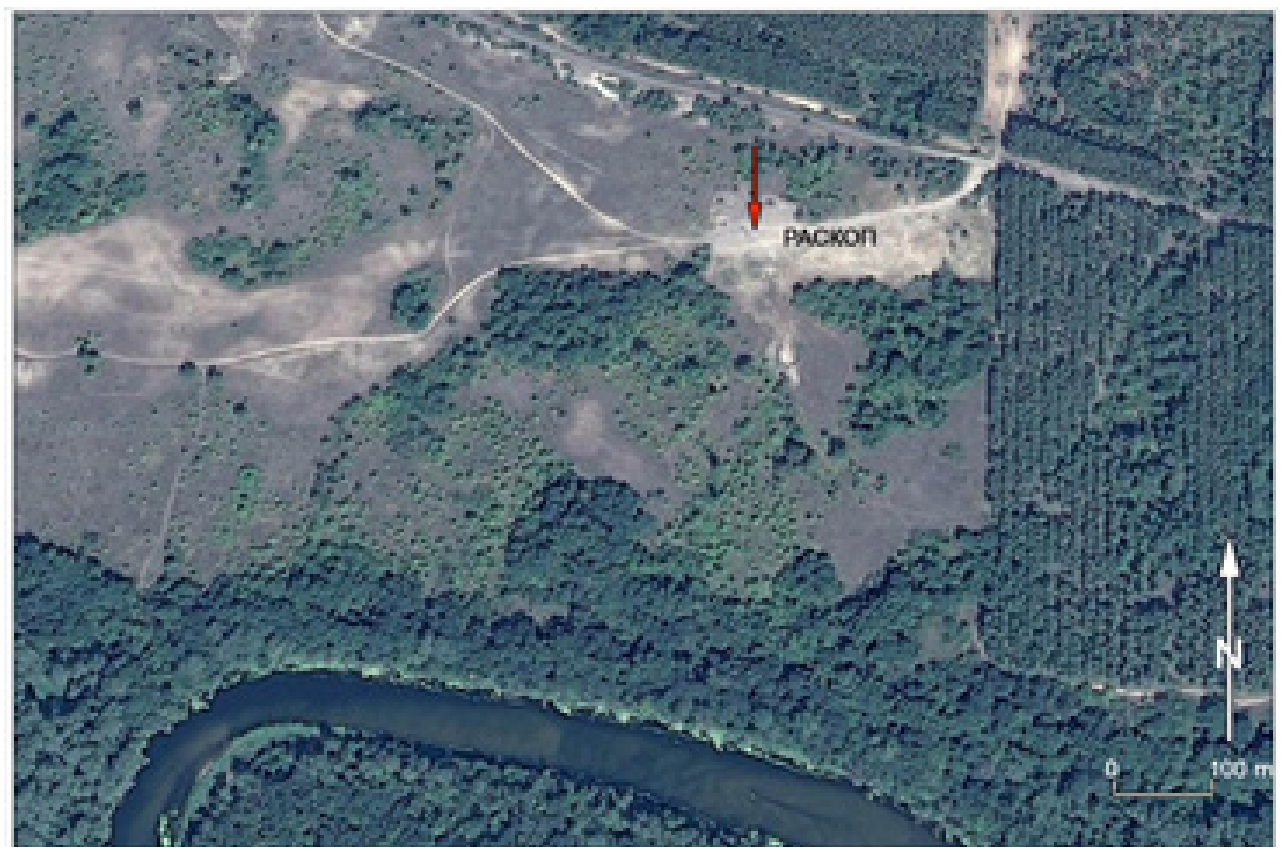

Рис. 2. Местоположение Орехово-Донеикой 3 на спутниковом снимке из Google Earth

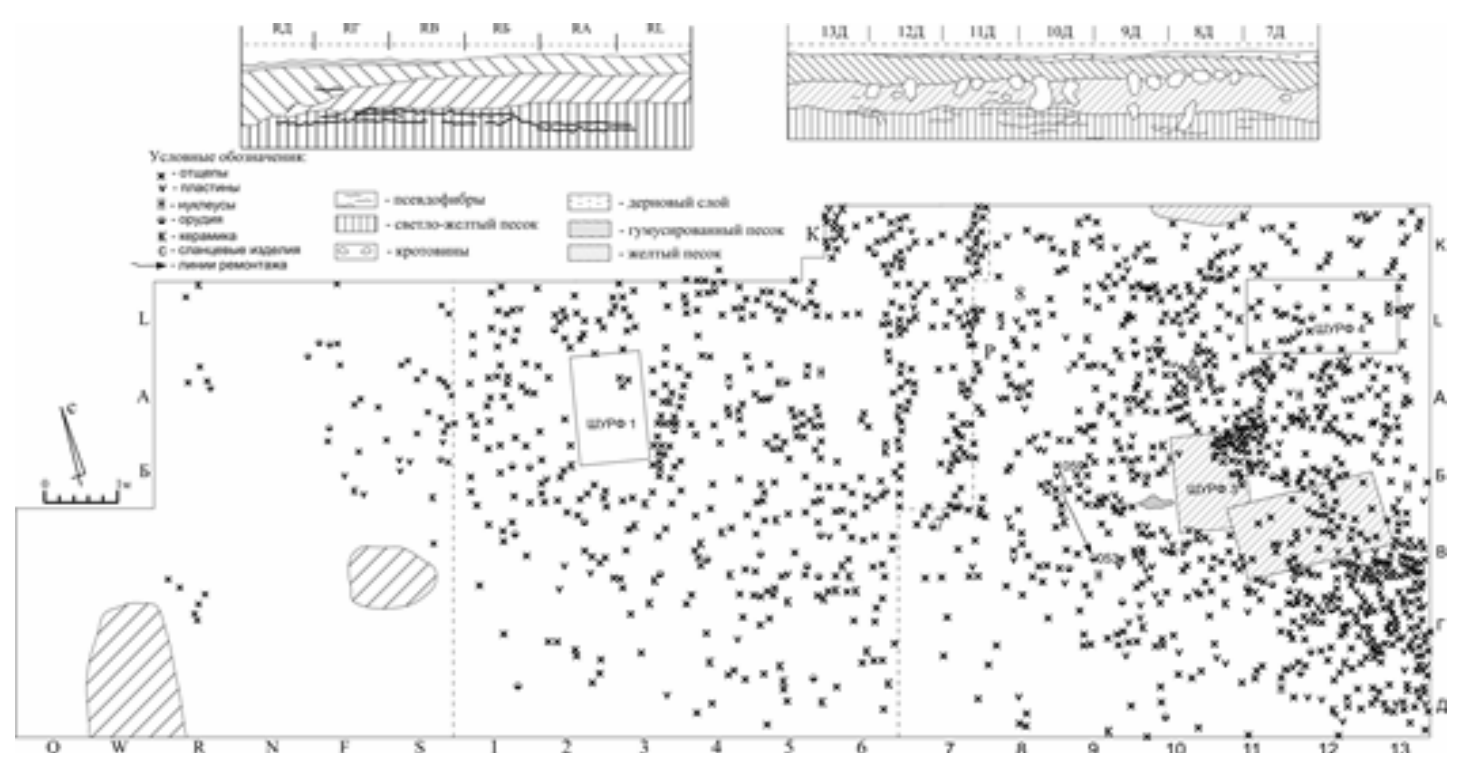

Рис. 3. Орехово-Донецчке 3: планиграфия культурных остатков на глубине 0,5-0, 7м и разрезы

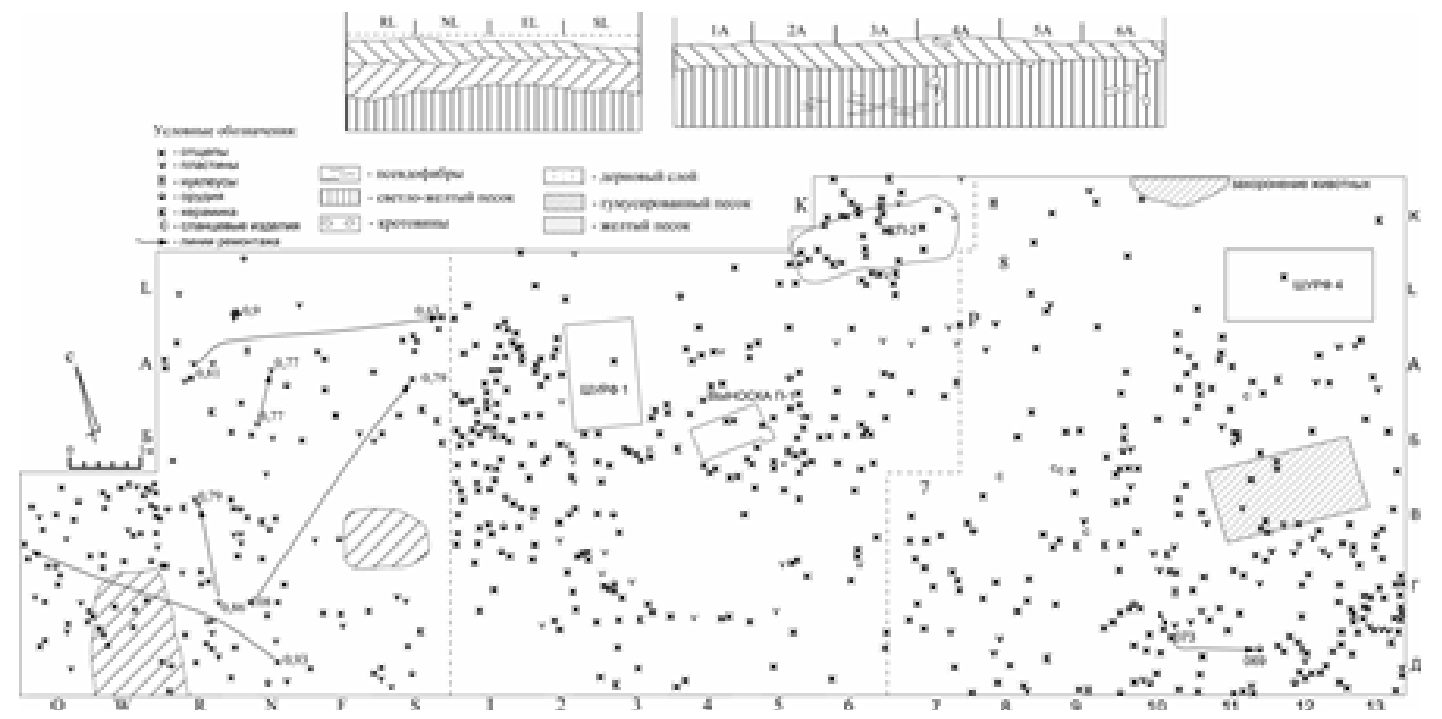

Рис. 4. Орехово-Донеиякое 3: планиграфия культурных остатков на глубине 0,7-1м и разрезы 

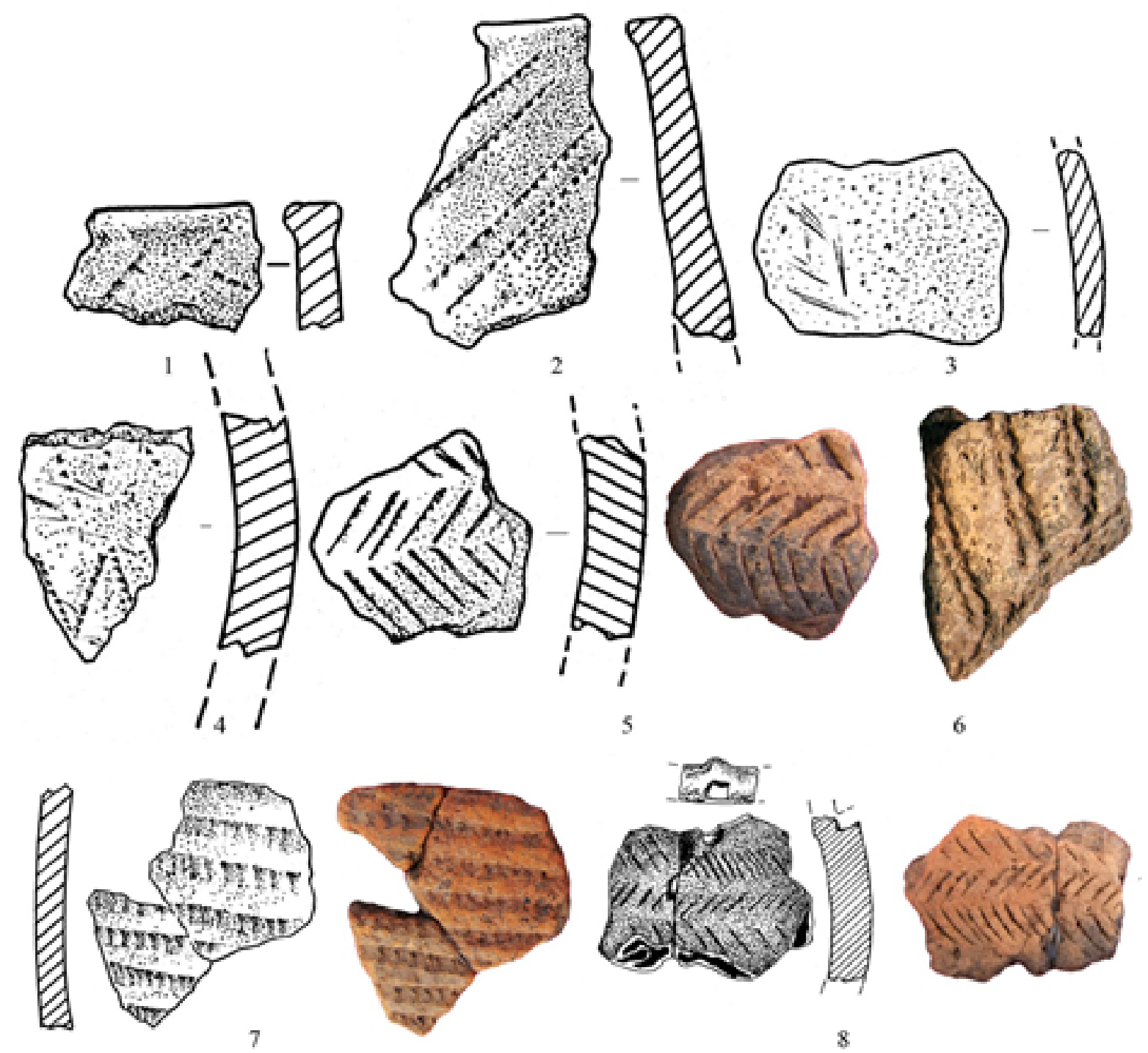

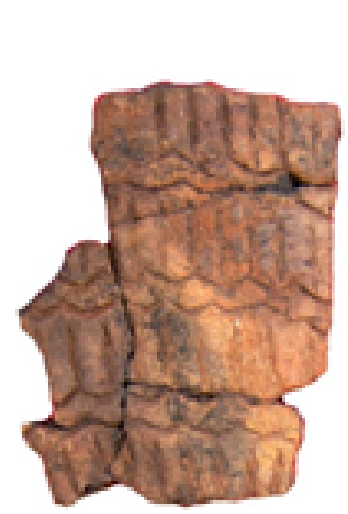

9

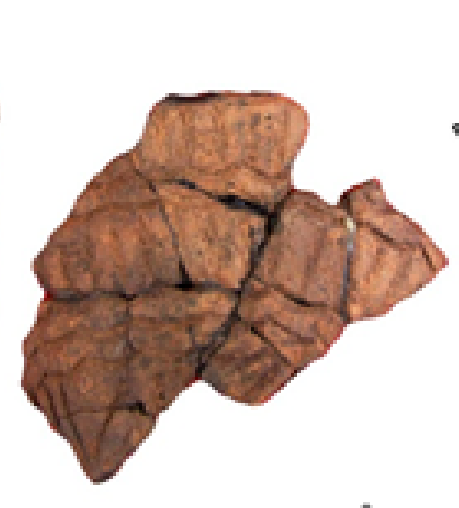

10

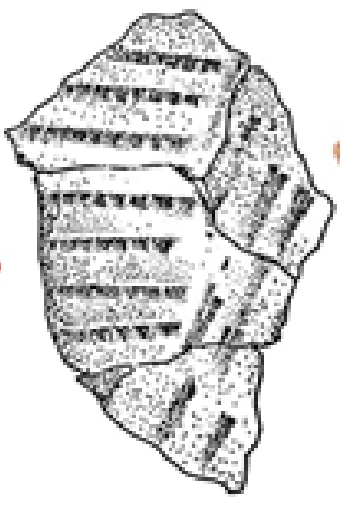

11

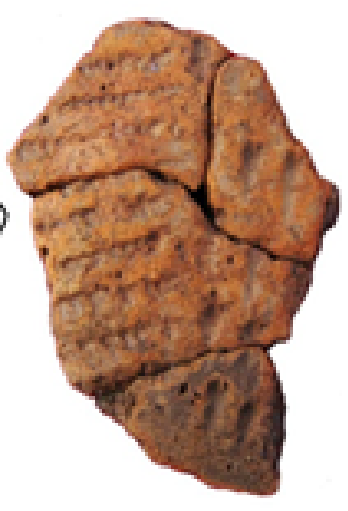

Рис. 5. Орехово-Донеикое 3: фрагменты керамики 

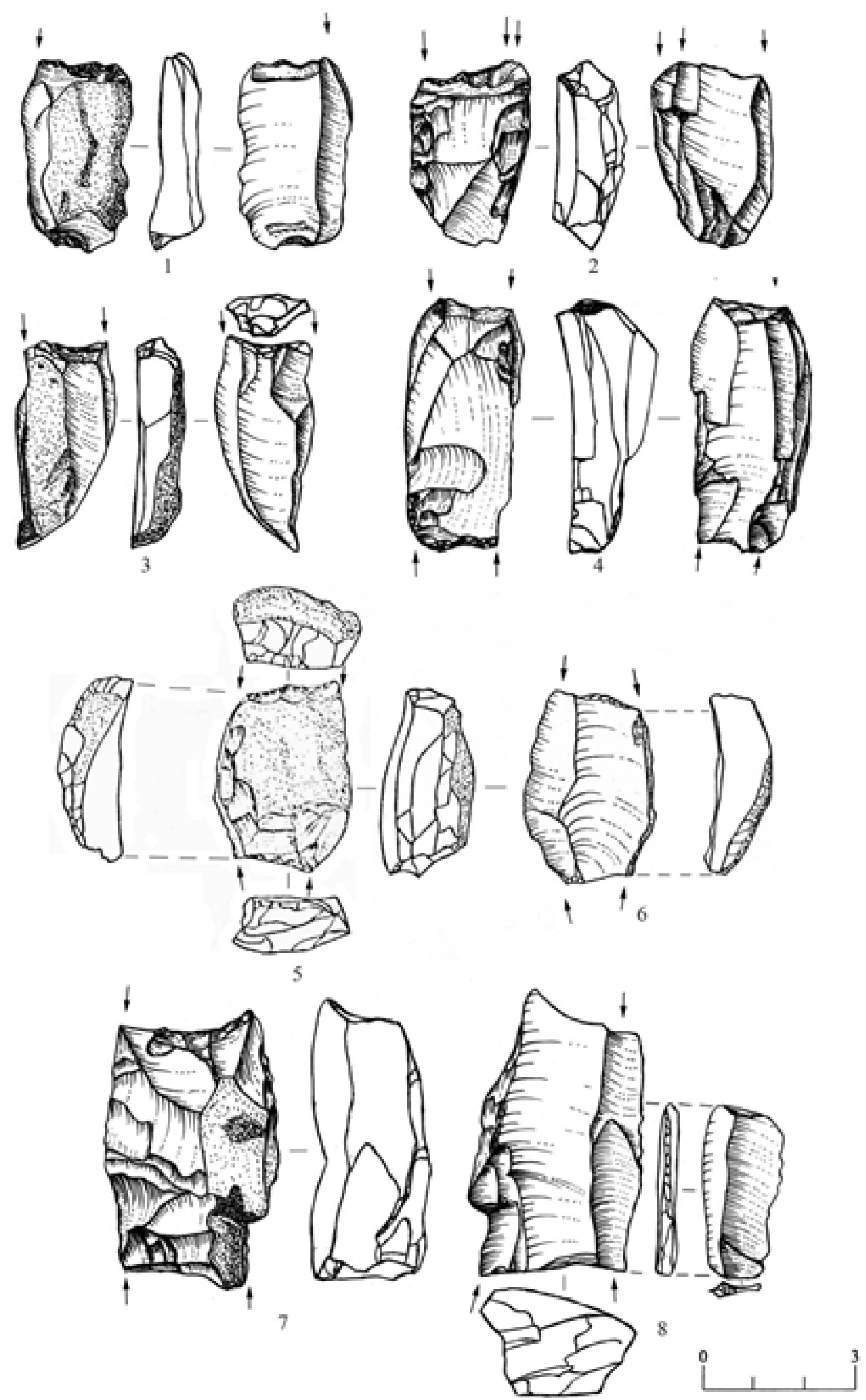

Рис. 6. Орехово-Донеикое 3: нуклеусы донеикого типа 

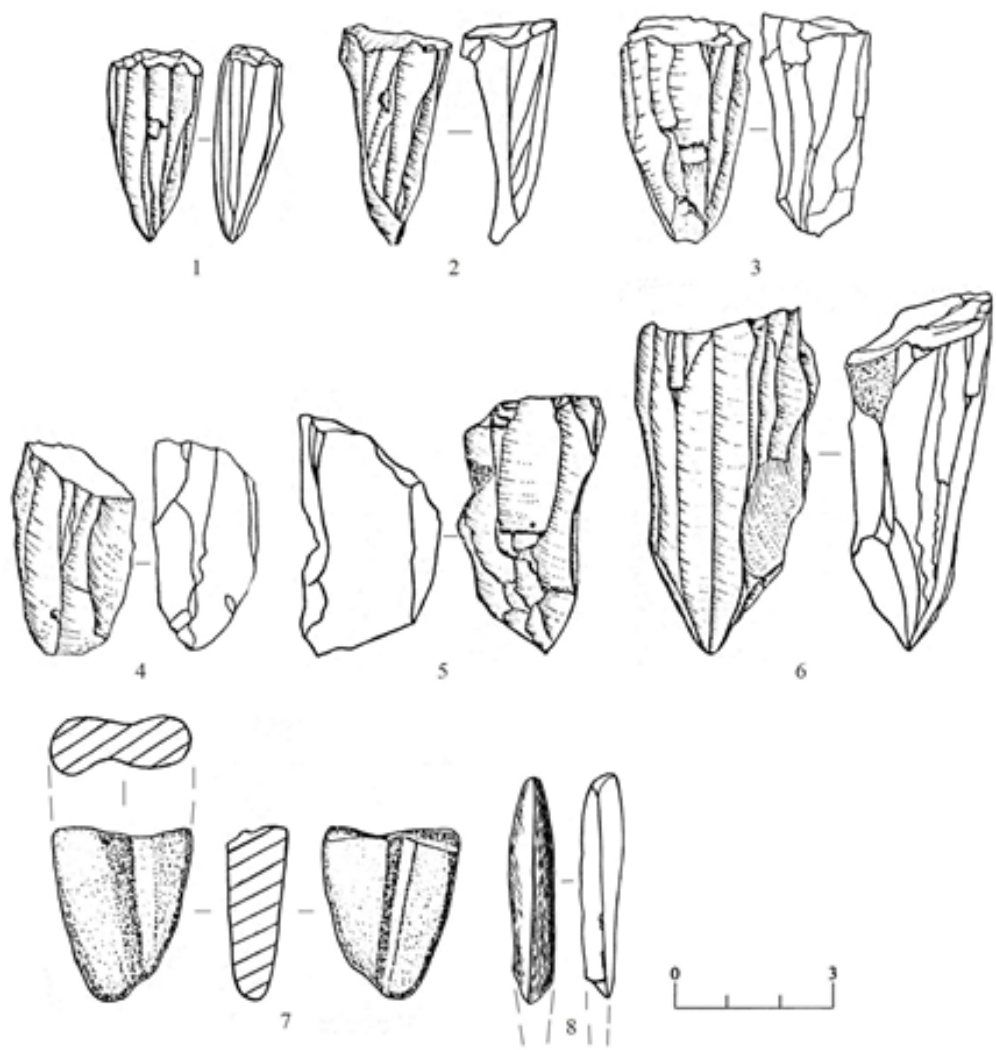

Рис. 7. Орехово-Донеикое 3: нуклеусы и изделия из камня
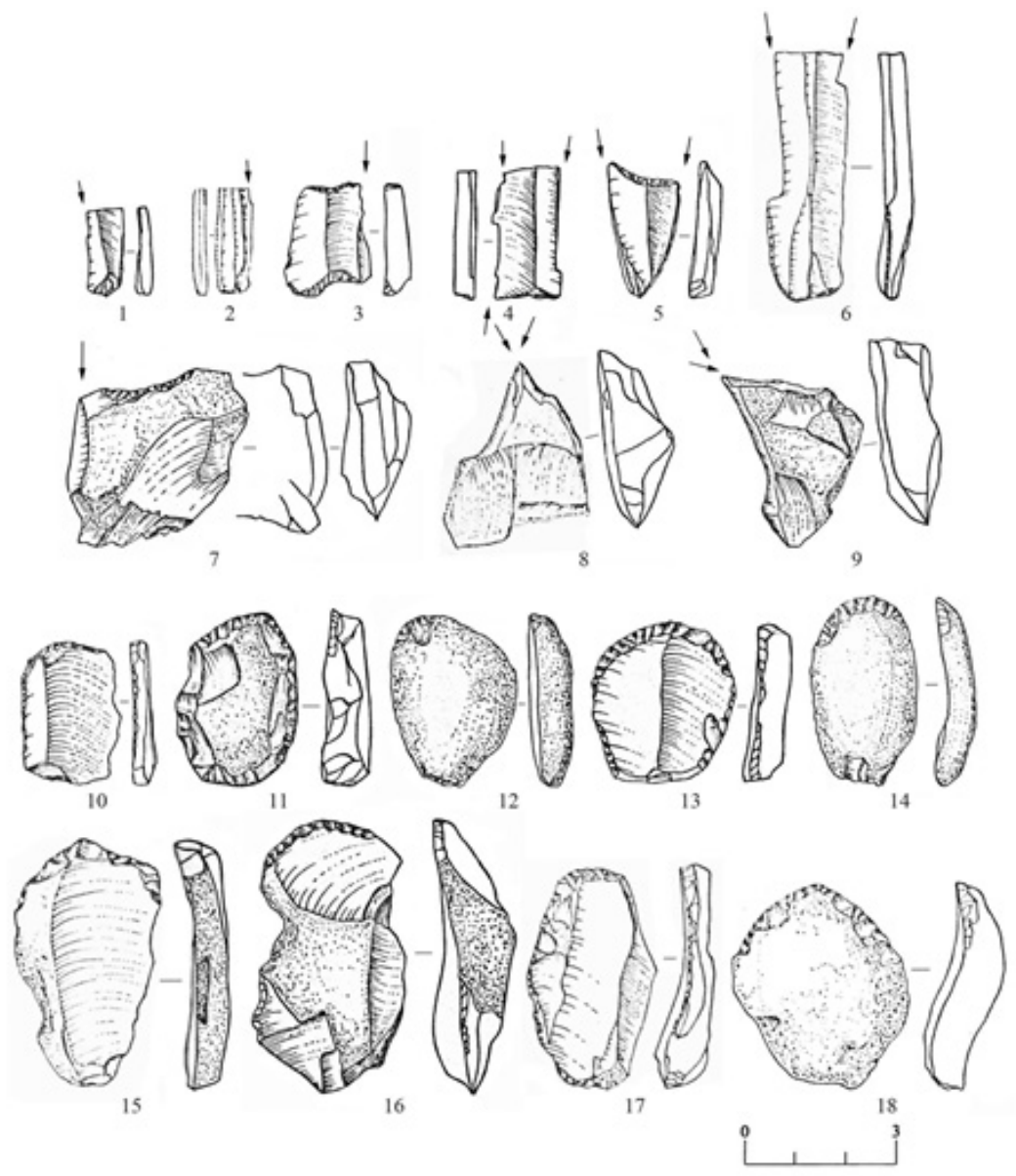

Рис. 8. Орехово-Донеикое 3: резиь и скребки 


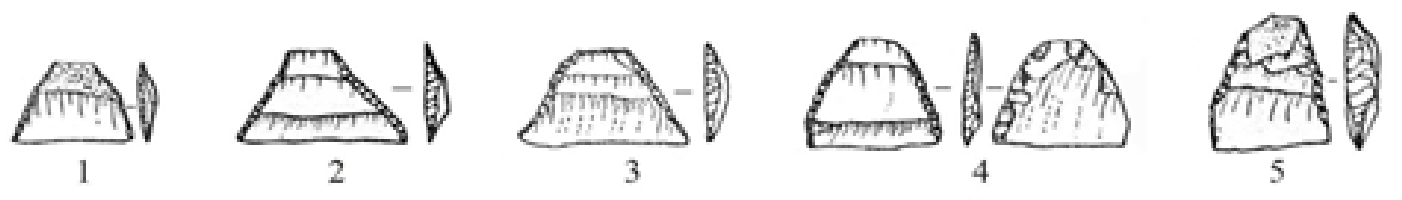

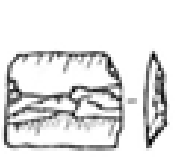

6

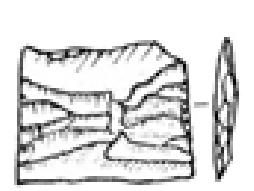

7

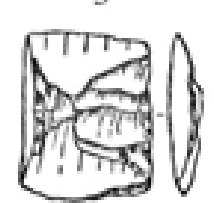

8

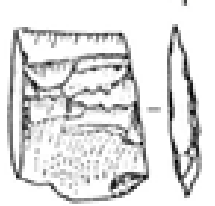

9
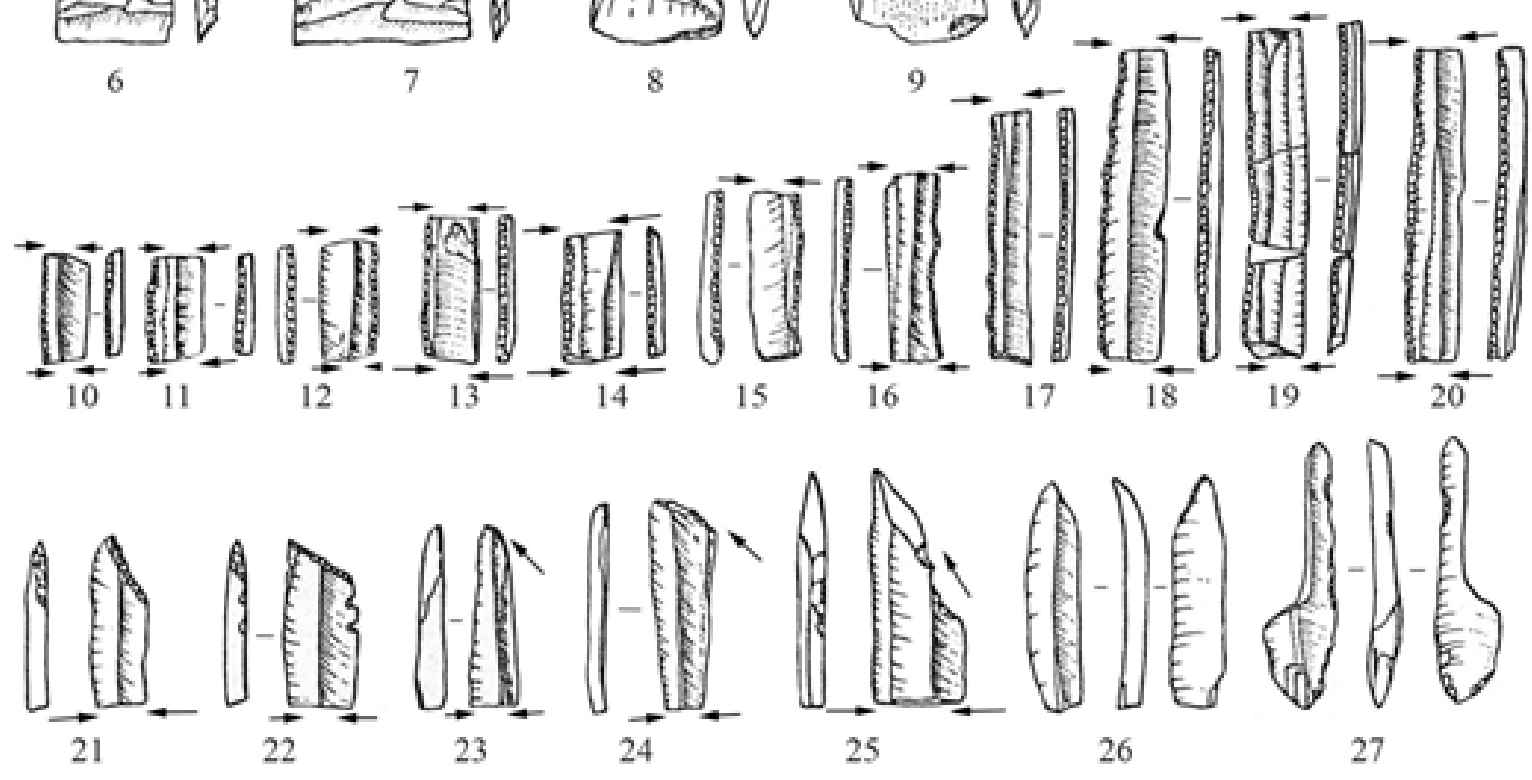

26
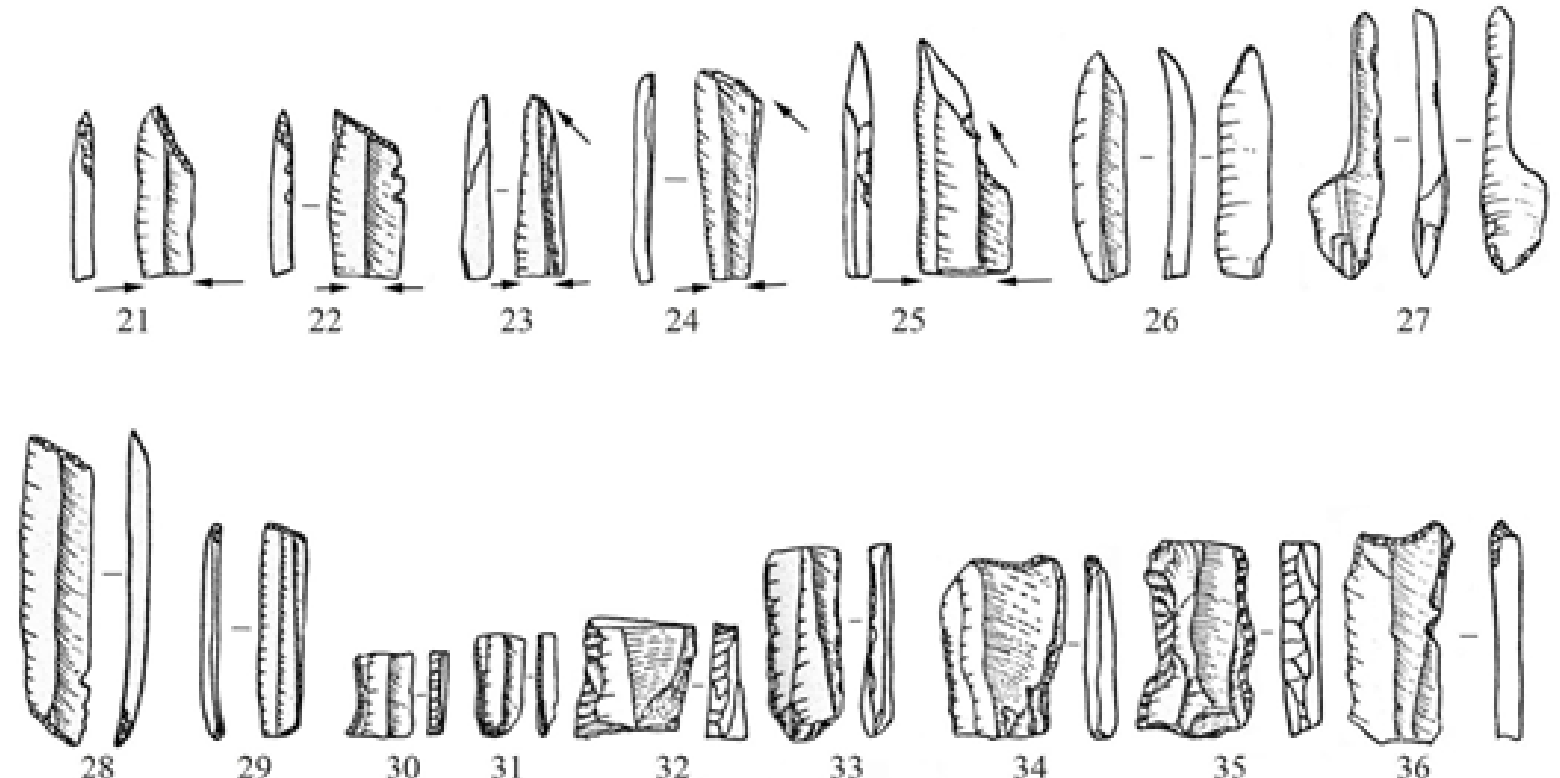

29
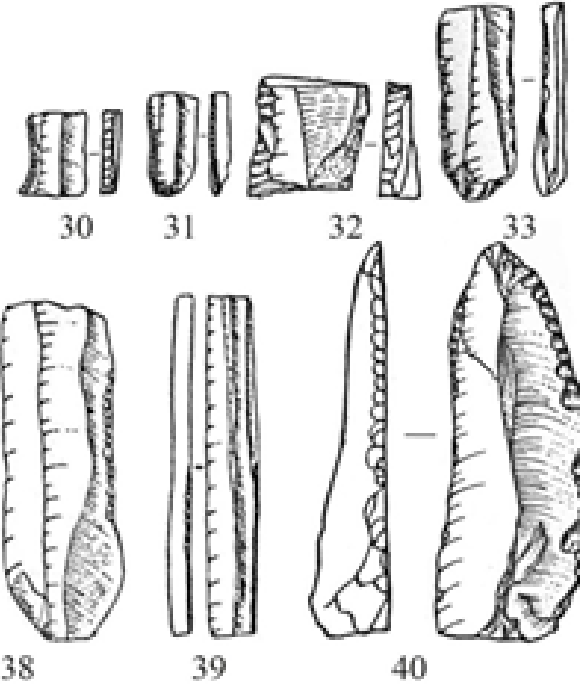

39
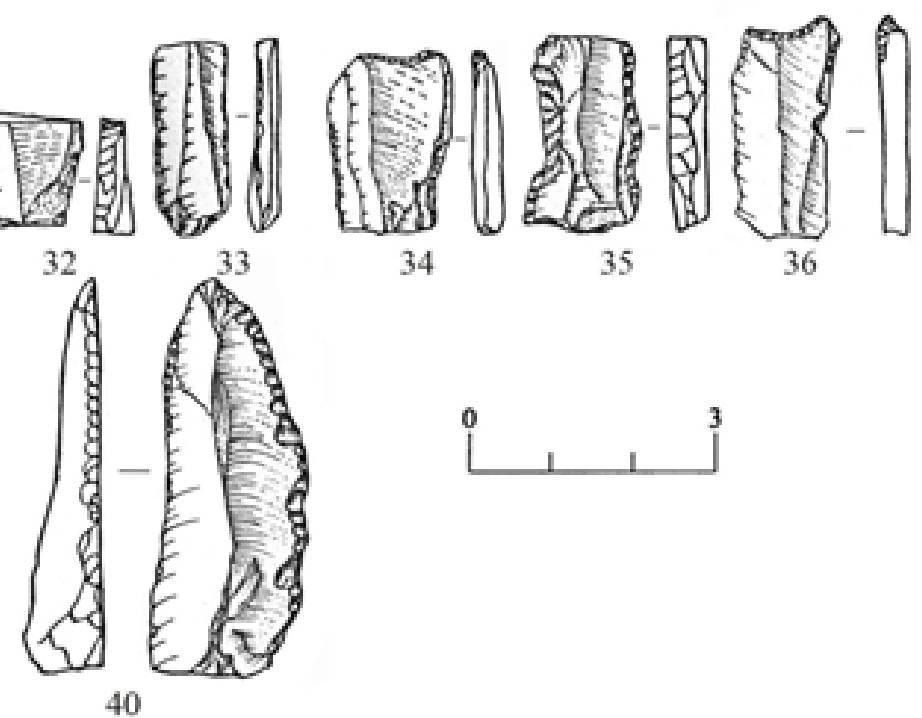

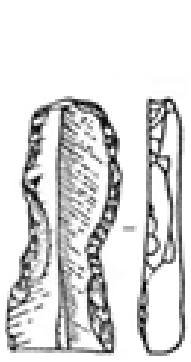

37

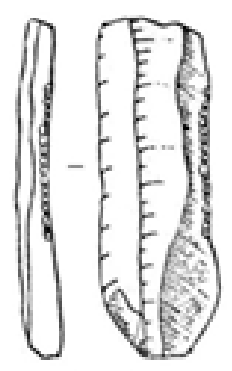

38

34

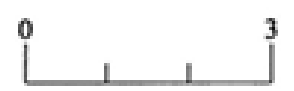

Рис. 9. Орехово-Донеикое 3: микролиты, пластинки с краевой ретушью, острия. Скоблевидные орудия 

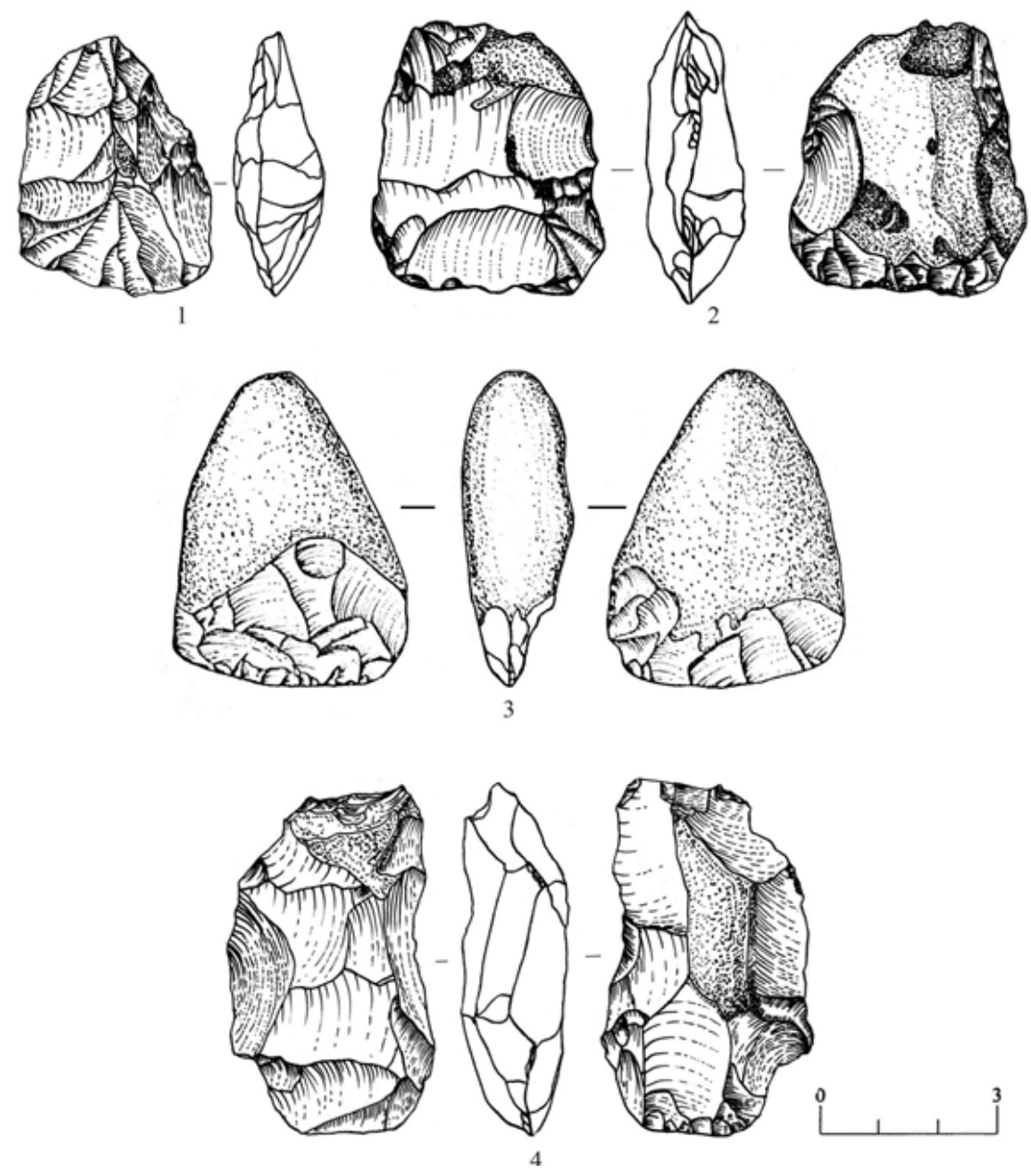

Рис. 10. Орехово-Донеикое 3: рубящие изделия из кремня

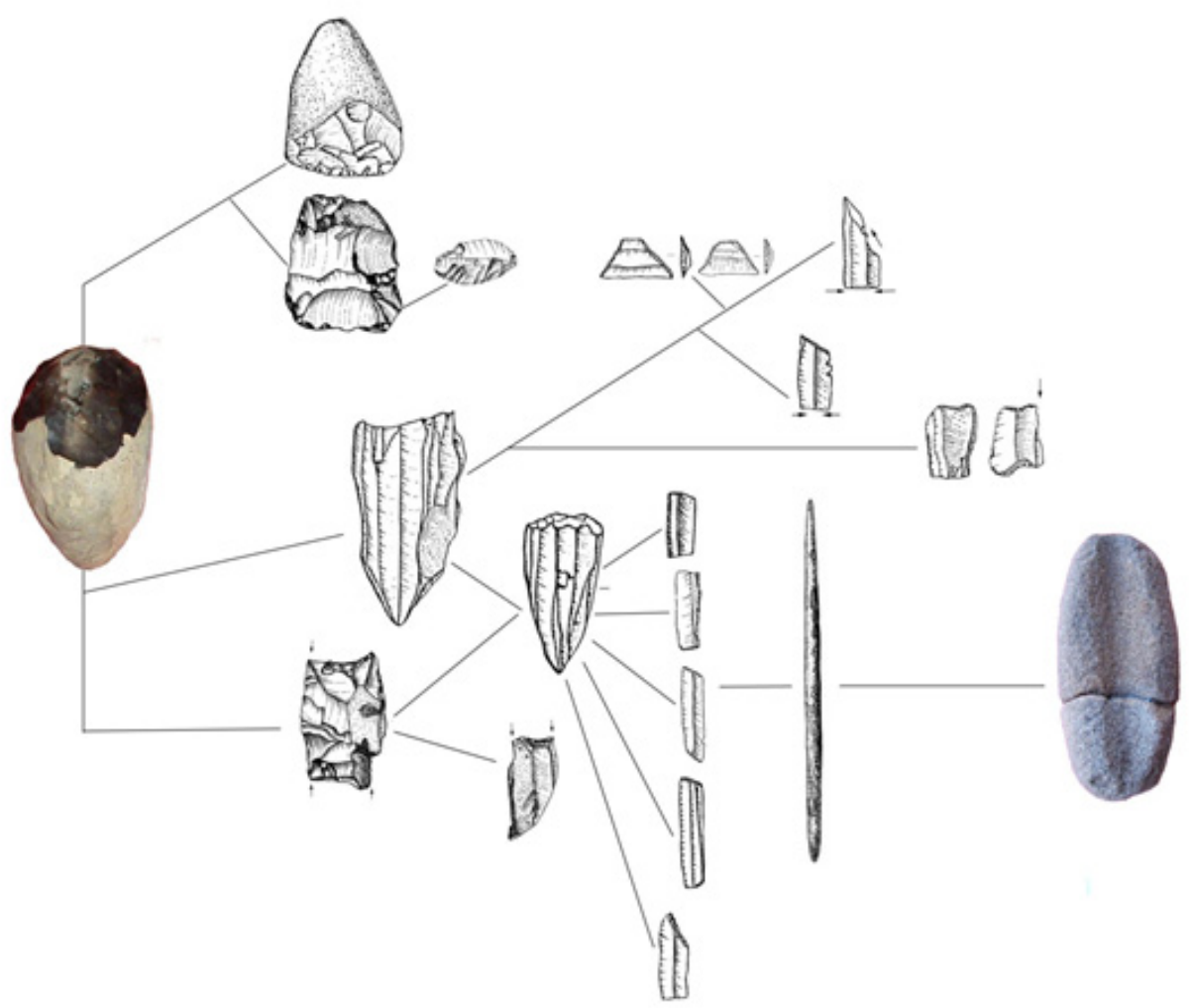

Рис. 11. Орехово-Донеикое 3: приничипиальная схема индустрии стоянки 


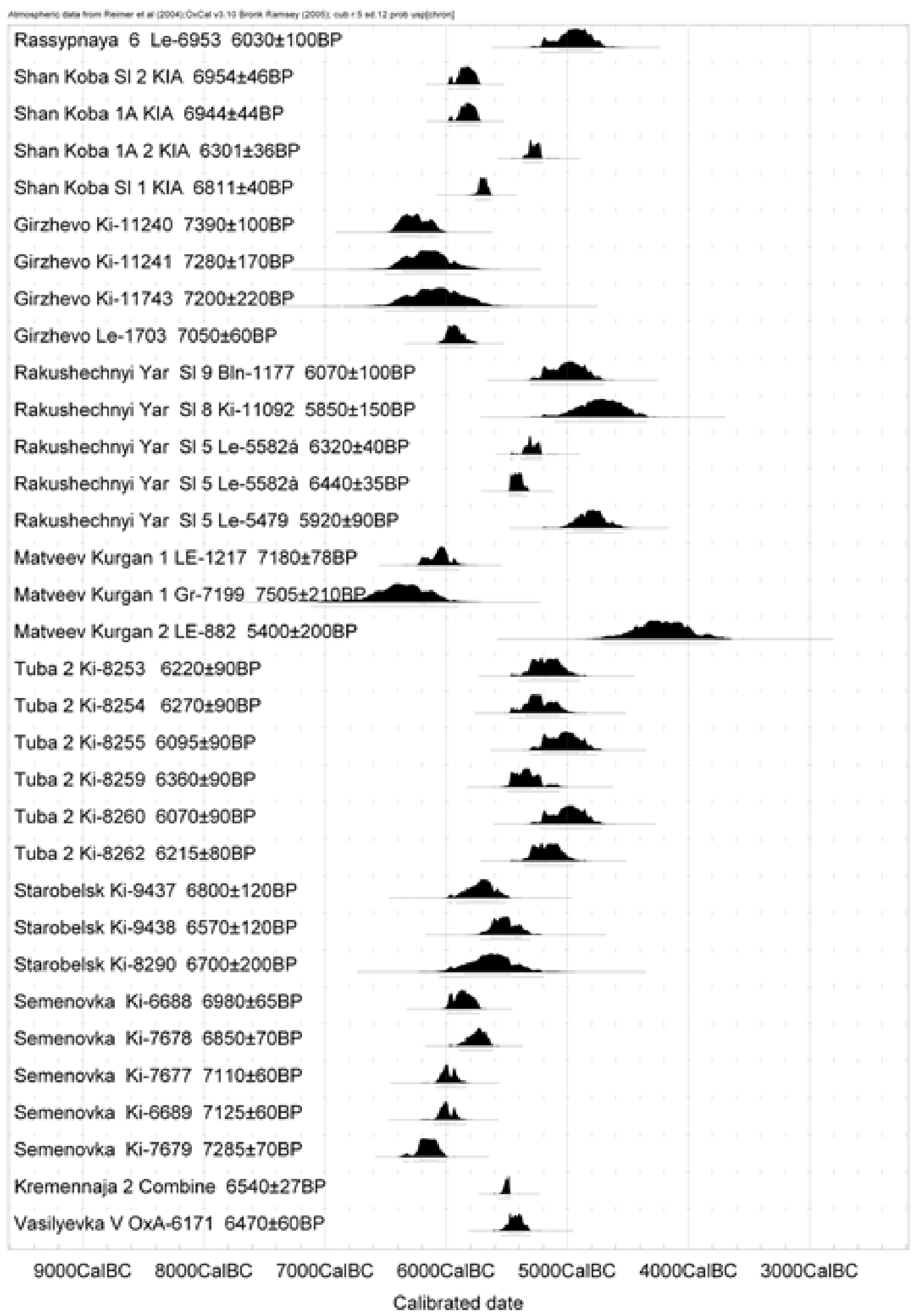

Рис. 12. Радиокарбоновые датировки памятников Юга Восточноевропейской равнины, фиксирующие начало использования трапеций со струганой спинкой

Данные по: Рассыпной 6 (публикуется впервые), по Шан-Кобе [69, Аbb.1], по Гиржево [70, табл. 5], по Ракушечному Яру [71, с. 17], по Матвееву Кургану [57] 
А.Ф. Горелик, А.В. Цыбрий СТОЯНКА ОРЕХОВО-ДОНЕЦКОЕ 3 В СРЕДНЕМ ПОДОНЦОВЬЕ ...

\begin{tabular}{|c|c|c|c|c|c|c|c|c|c|c|c|}
\hline 蛋 & 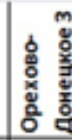 & 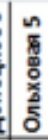 & 일 & 要 & 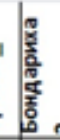 & 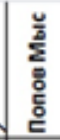 & 氶 & 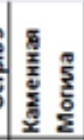 & 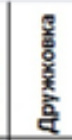 & $\begin{array}{l}\frac{N}{5} \\
\frac{2}{4} \\
\frac{2}{2} \\
\frac{2}{2}\end{array}$ & \\
\hline 1. & 0 & 6 & 2 & 2 & 2 & 0 & 2 & 0 & 0 & 0 & 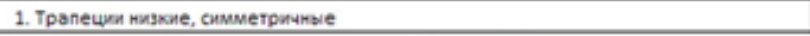 \\
\hline$\underline{2}$ & 2 & 0 & $3 / 1$ & 0 & 1 & 10 & 0 & o & 0 & 3 & 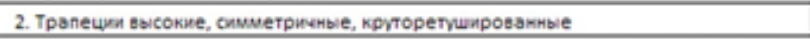 \\
\hline 3. & 1 & 3 & 3 & $0 / 1$ & o & 3 & 3 & o & $0 / 1$ & $2 / 2$ & 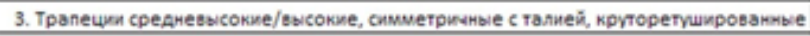 \\
\hline 4. & 2 & 4 & 7 & 3 & 4 & o & 1 & o & 3 & 2 & 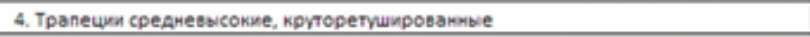 \\
\hline 5. & 1 & 0 & \% & 0 & \% & 0 & 0 & o & 0 & \% & 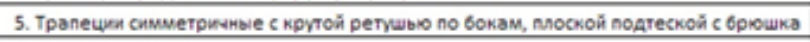 \\
\hline 6. & \% & 1 & 2 & \% & \% & 0 & 2 & \% & 0 & \% & 6. Cегvenты киякие \\
\hline 7. & 0 & 1 & 0 & 1 & 0 & 0 & 1 & 0 & 0 & 0 & 7. Cervertw сpеaneonsovie \\
\hline 8. & 0 & 1 & 0 & 0 & o & 0 & 0 & 0 & 0 & o & 8. Прамомтольнив, круторетушировакивй по трем сторонам \\
\hline 9. & 2 & 2 & 3 & 0 & 10 & 0 & 5 & 0 & 0 & \% & 9. Прамоитольнихи/трапеции со стритамой спиакой из широких пластия \\
\hline 10. & 2 & 0 & o & o & \% & 0 & 0 & \% & 0 & 0 & 10. прамоугольнакии со стругамой спиякой из пластинок \\
\hline 11. & 14 & 176 & 24 & 53 & 6 & 7 & 4 & ? & 7 & 2 & 11. Микроппастинки с приттплемны:м крзем \\
\hline 12. & 2 & 6 & 2 & $7 / 3$ & 1 & 1 & 1 & o & o & 10 & 12. Микропластинки с притупнетным крземи и косоксечемным концом \\
\hline 13. & 2 & 13 & 1 & 3 & 2 & 6 & \begin{tabular}{|l}
10 \\
$(247)$
\end{tabular} & 0 & 0 & 0 & 13. Острия домецкие со сломанным основакием \\
\hline 14. & to & 0 & to & 1 & 10 & 1 & 0 & To & to & 10 & 14. Микрорезцы \\
\hline 15. & 1 & o & 1 & 10 & 10 & o & 0 & o & o & 1 & 15. Псевяомикрорезец \\
\hline 16. & 1 & 5 & 4 & 2 & \% & 0 & 1 & 0 & 1 & \% & 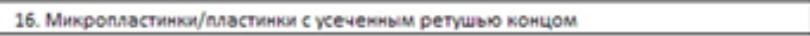 \\
\hline 17. & 1 & 0 & 0 & 0 & 0 & 0 & 0 & 0 & 0 & 0 & 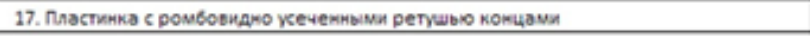 \\
\hline 18. & 3 & 3 & 1 & 0 & 2 & 0 & 18 & . & 0 & \% & 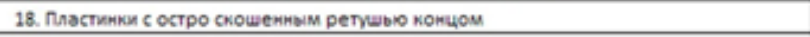 \\
\hline 19. & 1 & 0 & 1 & 2 & 1 & + & 0 & o & 0 & 10 & 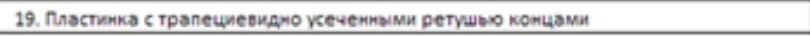 \\
\hline 20. & 8 & 1 & 2 & \% & 1 & + & 4 & \% & 0 & \% & 20. Пизстинкии с краевой ретишью и встречными вьемками по краям \\
\hline 21. & 10 & 18 & 30 & 5 & 6 & . & 30 & 0 & 7 & 10 & 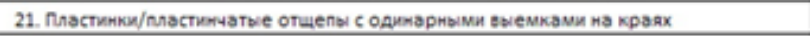 \\
\hline 22. & 13 & 105 & 44 & 17 & 30 & 95 & 940 & . & 3 & 10 & 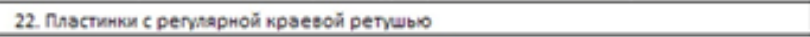 \\
\hline 23. & 9 & 106 & 230 & 26 & 7 & 200 &. & . & 4 & 2 & 23. Пластинки с крзевой ретишью нерегүлармой \\
\hline 24. & 7 & 49 & 4 & 1 & 1 & 0 & o & o & 10 & 10 & 24. Пластинки, о6работамные ретулармой пологой ретушью \\
\hline 25. & 2 & 7 & 2 & 2 & 10 & 12 & 82 & ... & to & to & 25. Вкпадышии кххрекскоого типа \\
\hline 26. & 10 & 15 & 3 & 2 & 10 & 0 & 0 & 0 & o & 10 & 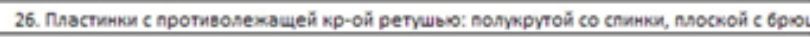 \\
\hline 27. & 8 & 23 & 3 & 2 & \% & 0 & 0 & 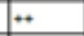 & o & 0 & 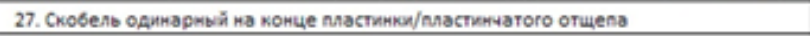 \\
\hline 28. & 3 & 4 & 1 & 1 & \% & + & o & .* & 8 & 10 & 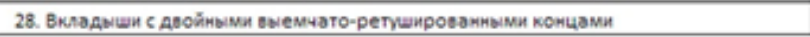 \\
\hline
\end{tabular}

Рис. 13а. Сериационная таблица типов инвентаря памятников Бондарихинского этапа Донецкой культуры и некоторых других культурно/ территориально сопряженных комплексов

\begin{tabular}{|c|c|c|c|c|c|c|c|c|c|c|c|}
\hline 2a. & $\mathrm{a}$ & 12 & la & lo & a & + & lo & lo & a & lo & 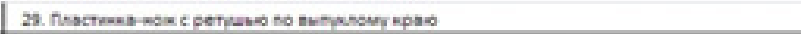 \\
\hline 50. & 8 & 5 & is & p & e & Q & 1 & e & is & o & 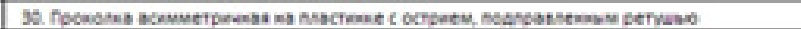 \\
\hline 泣. & a & 6 & g & p & 2 & 0 & 0 & 0 & 3 & 0 & 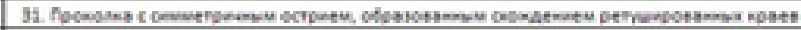 \\
\hline 12 & i & b & 0 & 0 & 0 & o & 0 & 10 & 2 & 10 & 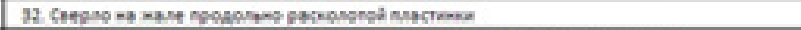 \\
\hline 21 & b & 4 & 2 & 0 & 0 & 0 & 0 & 0 & 5 & 0 & 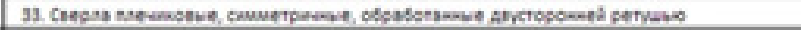 \\
\hline se & 2 & is & B & 3 & 3 & 6 & 6 & 0 & 3 & 2 & 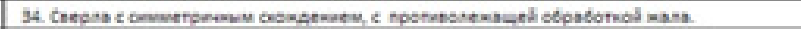 \\
\hline 5s. & 9 & 3 & i & p & e & 9 & 9 & 0 & 9 & 0 & 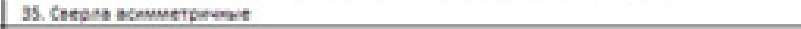 \\
\hline s. & b & 3 & 2 & o & 0 & 20 & 10 & o & a & o & 36. Fasetona \\
\hline n. & 23 & 120 & 41 & 17 & 32 & es & 230 & - & 3 & s & 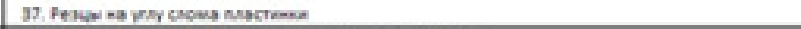 \\
\hline II. & 4 & 5 & 3 & 2 & 1 & 2 & 4 & $\ldots$ & 3 & $1 / 2$ & 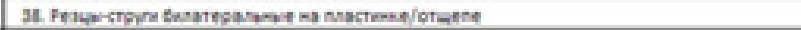 \\
\hline sin. & 3 & 8 & 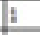 & 2 & 4 & 4 & 1 & + & I & 2 & 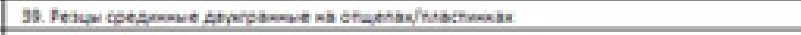 \\
\hline et. & 3 & 1 & 5 & p & 6 & 19 & 0 & $\ldots$ & a & 0 & 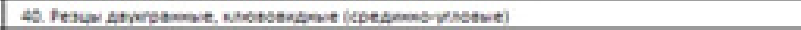 \\
\hline 4 . & I & 5 & 5 & o & o & 13 & 0 & 0 & 9 & o & 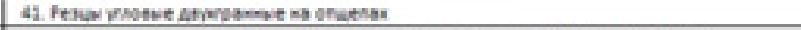 \\
\hline 42 & 4 & 43 & 2 & 1 & 9 & 4 & 2 & - & 2 & 1 & 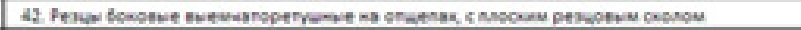 \\
\hline 4s & 2 & 12 & $\mathrm{t}$ & 0 & 0 & s & 2 & 0 & i & 1 & 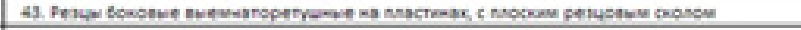 \\
\hline 4. & 2 & at & $\mathrm{i}$ & 0 & 2 & 3 & 2 & - & $\mathrm{a}$ & 2 & 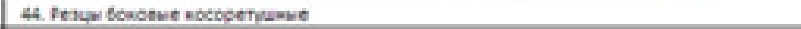 \\
\hline as. & 2 & 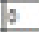 & b & 0 & p & 9 & 0 & + & 2 & 0 & 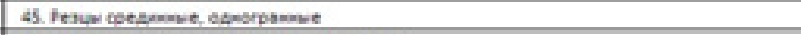 \\
\hline es. & 10 & 609 & as & 1 & 90 & $10 / 25$ & 3 & 1/Mano & $3 / 10$ & 2 & 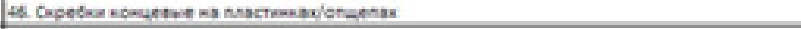 \\
\hline 47. & 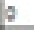 & 7 & 2 & p & 1 & p & 21 & 0 & a & 0 & 47. Copeter nomutwe, Anolese \\
\hline 48. & 2 & 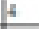 & 3 & p & 0 & 9 & 9 & p & a & 0 & 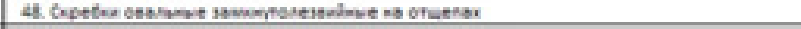 \\
\hline eat. & 0 & is & b & 0 & 3 & 0 & 0 & 4 & 2 & 0 & 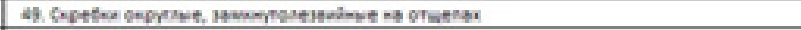 \\
\hline$\$ 2$ & 0 & 2 & 2 & 0 & 0 & 2 & 160 & 0 & 2 & 0 & 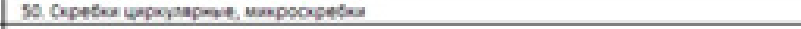 \\
\hline 32. & 5 & tas & 4 & 2 & 11 & 17 & 20 & o & 2 & 0 & 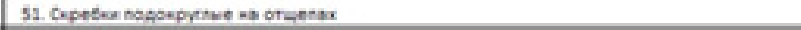 \\
\hline 32 & 3 & $\mathbf{M}$ & 12 & e & 7 & 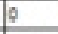 & 4 & 0 & 2 & 1 & 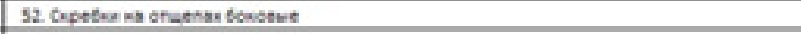 \\
\hline se & e & as & 30 & 1 & 0 & Q & 1190 & 0 & a & 1 & 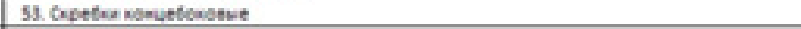 \\
\hline sus & 20 & 267 & 5 & 7 & 1s & 4 & 0 & 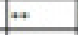 & 3 & 15 & 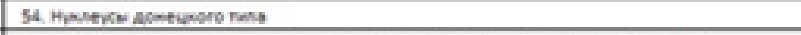 \\
\hline s. & 3 & to & 3 & 2 & s & 2 & 5 & 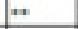 & 4 & 1 & 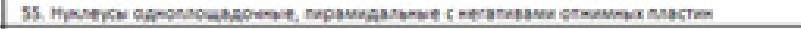 \\
\hline s. & 2 & 60 & 3 & 0 & 1 & 6 & 16 & - & 4 & 3 & 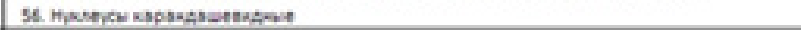 \\
\hline 57. & 2 & a & 1 & 2 & p & 2 & 5 & $\rightarrow$ & a & 3 & 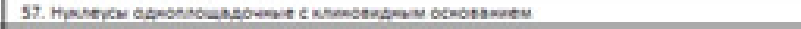 \\
\hline se. & 2 & a & I & p & p & o & 1 & 0 & [9 & 0 & 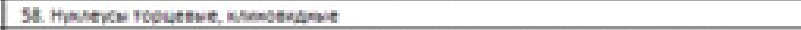 \\
\hline 39. & 0 & at & 20 & p & 10 & 4 & 6 & 0 & 3 & 15 & 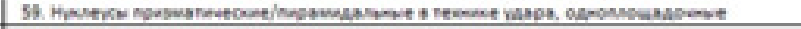 \\
\hline Q2 & 0 & 凡 & 4 & 0 & 6 & 1 & 4 & 10 & 2 & 2 & 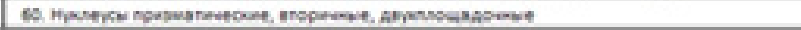 \\
\hline
\end{tabular}

Рис. 13б. Сериациионная таблица типов инвентаря памятников Бондарихинского этапа Донецикой культуры и некоторых других культурно/ территориально сопряженных комплексов 


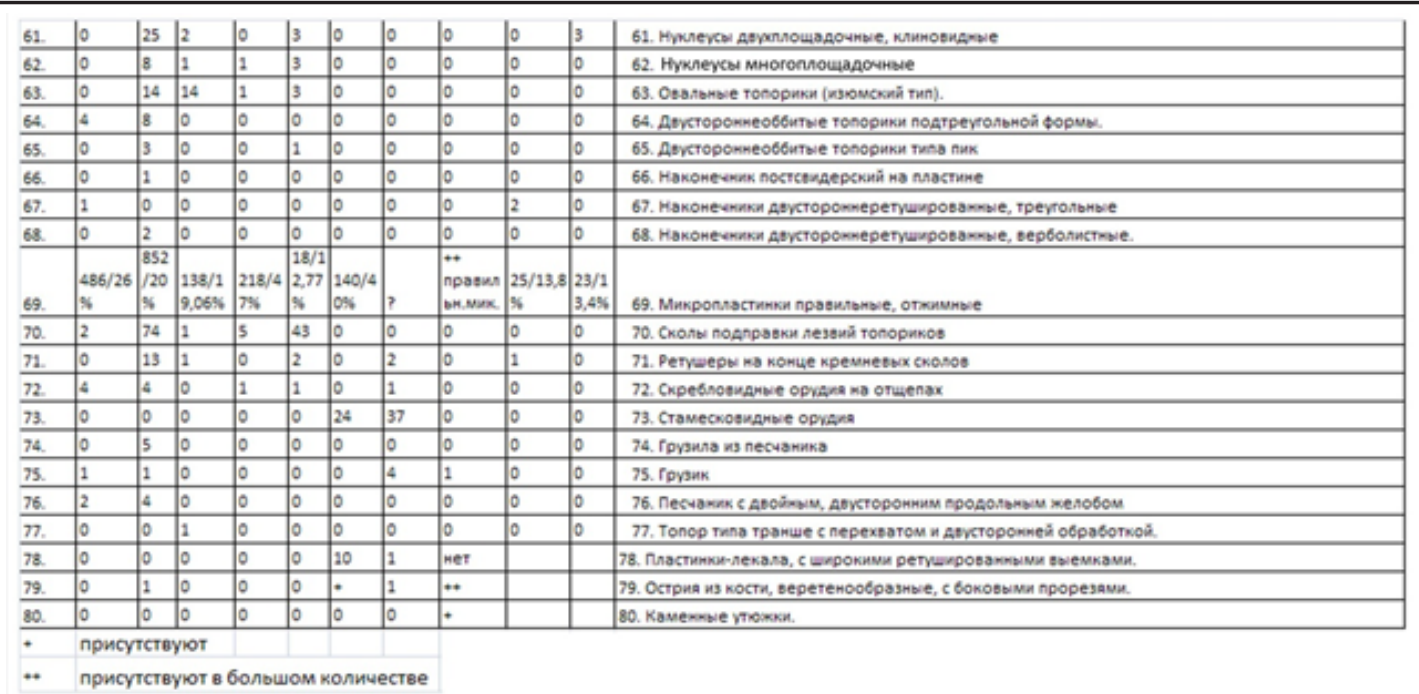

Рис. 13в. Сериаџионная таблица типов инвентаря памятников Бондарихинского этапа Донецкой культуры и некоторых других культурно/ территориально сопряженных комплексов

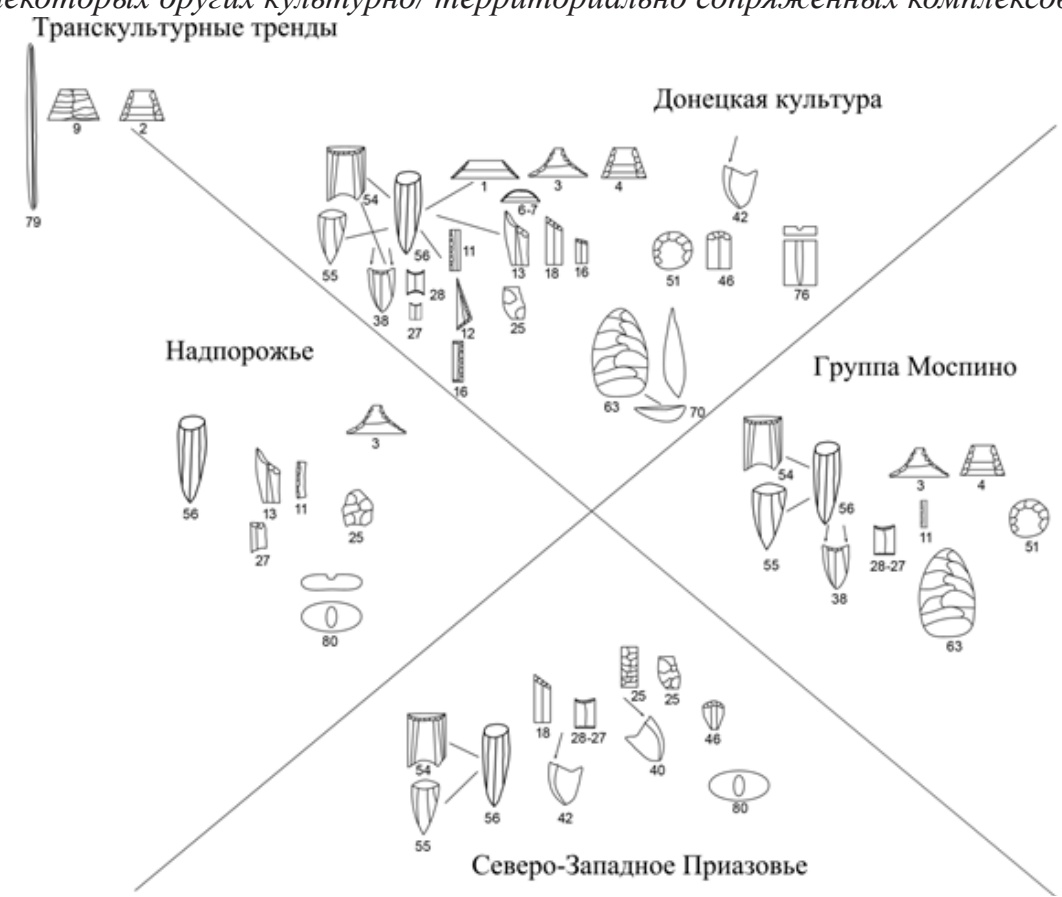

Рис. 14. Опорная схема инвентаря памятников начала неолита на территории Северского Дониа, Донецкого Кряжа, Северо-Западного Приазовья и Надпрожья

\section{THE CAMPSITE ORECHOVO-DONETSKOE 3 IN THE MIDDLE STREAM OF THE SEVERSKY DONETS BASIN. ON THE CHARACTERISTIC OF ONE OF THE TURNING POINT IN THE HISTORY OF THE DNIEPER-DONETS NEOLITHIC}

(C) 2014

A.F. Gorelik, Candidate of Historical Sciences, associate professor, Independent Researcher Bochum (Germany)

A.V. Tsybriy, Candidate of Historical Sciences, senior researcher

Don archaeological society, Rostov-Don (Russia)

Annotation: The materials of investigations of the early Neolithic campsite Orechovo-Donetskoe 3 in the basin of the Seversky Donets are published in this paper for the first time. The authors argue, that this site belongs to a number of numerous other sites of the hunters, collectors and fishers of so called Bondaricha stage who have extended in 6 thousand calBC in the territory of a left bank of the Seversky Donets and partly, in the Dnieper rapids area. They analyse the reasons of considerable demographic transformations at a boundary between Mesolithic and Neolithic in this region, regard the ways of communications and contacts of the population of Donets culture, show the importance of social changes as a prerequisite of process of Neolithisation.

Keywords: mesolithic; Neolithic; Neolithisation; turning point; Donets Culture. 